\title{
GENETIC PREDICTIONS OF FUTURE DANGEROUSNESS: IS THERE A BLUEPRINT FOR VIOLENCE?
}

\author{
ERICA BEECHER-MONAS* AND EDGAR GARCIA-RILL**
}

\section{INTRODUCTION}

The brave new world of genomics, spurred on by the Human Genome Project, presents tantalizing possibilities for developments in criminal law as well as advances in medicine and understanding disease. DNA identification testing has become commonplace in the courts, transforming the criminal justice system, demonstrating innocence, and identifying perpetrators. Already it is clear that DNA testing will be used as a way of predicting which medical treatments will be effective. With predictive medicine becoming a reality, surely predicting human behavior cannot be far behind.

The link between crime and genetics is hardly a new idea. Since at least the late nineteenth century, courts and prisons have reflected attempts to discriminate between the innately criminal and those who acted merely by force of circumstance, whose crimes would not pose a future danger to society. ${ }^{1}$ To aid this distinction, predictions of future dangerousness became vital to the criminal justice system. This legacy has persisted despite the enactment of civil rights legislation that did away with the more overtly racist laws derived from eugenics. As a result, predictions of future dangerousness now dominate death penalty

Copyright ( 92006 by Erica Beecher-Monas and Edgar Garcia-Rill

This Article is also available at http://law.duke.edu/journals/lcp.

* Professor of Law, Wayne State University Law School. J.D., University of Miami School of Law; LL.M \& J.S.D., Columbia University School of Law.

** Director of the Center for Translational Neuroscience, research arm of the Jackson T. Stephens Spine \& Neuroscience Institute. Dr. Garcia-Rill is also a Professor in the Department of Neurobiology \& Developmental Sciences and the Department of Psychiatry at the University of Arkansas for Medical Sciences (UAMS).

1. Cesare Lombroso, an influential criminologist, claimed that criminals were atavistic throwbacks to the apes, characterized by physical stigmata, as well as a high threshold for pain, an inability to blush, and a propensity for tattoos. CESARE LOMBroso, CRIME: ITS CAUSES AND REMEDIES 365 (Henry P. Horton trans., 1918). See also STEPHEN J. Gould, ThE MismeAsure of MAN 153-72 (1996) (discussing Lombroso's influence on criminal law and the fallacy of his claims to predict innate criminality). According to Lombroso, although dangerous criminals should be removed from society, little would be gained by incarcerating victims of circumstance, including men who kill their adulterous wives in the heat of passion. LOMBRoso, supra, at 138. 
sentencing determinations and the commitment proceedings of sexually violent predators. $^{2}$

Surprisingly, although the stakes are high for their subjects, the predictions receive little judicial or legislative scrutiny. Courts and legislatures are well aware of the unscientific nature of these predictions; nonetheless, they continue to demand them. ${ }^{3}$ Responding to this continued demand, researchers have attempted to improve the accuracy of their predictions of future dangerousness by developing actuarial instruments to assess the risk of repeated violence in offenders and psychiatric patients by examining a number of factors, scored on a scale with points varying according to the particular instrument. ${ }^{4}$ Each instrument evaluates different risk factors, and scores each differently. No one method is particularly predictive; ${ }^{5}$ but the general consensus is that such instruments are superior to clinical judgment alone. ${ }^{6}$ Whether future dangerousness predictions can meet standards of scientific validity, and what, if anything, can be done to improve them, are highly debatable issues. ${ }^{7}$ The question posed by behavioral genetics is whether molecular biology can improve this record.

Genetic information, including behavioral genetics, has exploded under the influence of the Human Genome Project. ${ }^{8}$ Virtually everyone agrees that genes

2. Lest one think that racism and bigotry have disappeared from predictions of future dangerousness, it is worth noting that "whites are more likely to view African American defendants as dangerous and violent than they [are likely to] view white defendants." Donna Coker, Foreword: Addressing the Real World of Racial Injustice in the Criminal Justice System, 93 J. CRIM. L. \& CRIMINOLOGY 827, 876 (2003).

3. See Alexander Scherr, Daubert \& Danger: The "Fit" of Expert Predictions in Civil Commitments, 55 HASTINGS L.J. 1, 2-3 (2003) (commenting that courts are extraordinarily receptive to expert future dangerousness testimony, even though they are well aware of its scientific unreliability).

4. Actuarial risk assessment "uses an equation, a formula, a graph, or an actuarial table to arrive at a probability, or expected value, of some outcome." William M. Grove \& Paul E. Meehl, Comparative Efficiency of Informal (Subjective, Impressionistic) and Formal (Mechanical, Algorithmic) Prediction Procedures: The Clinical-Statistical Controversy, 2 PsYCHOL. PUB. POL'Y \& L. 293, 294 (1996).

5. See, e.g., Neil M. Malamuth et al., Risk Assessment: Discussion of the Section, in 1989 ANNALS N.Y. ACAD. SCI., SEXUALlY COERCIVE BEHAVIOR: UNDERSTANDING AND MANAGEMENT 236, 237 (Robert A. Prentky et al. eds., 2003) [hereinafter SEXUALly COERCIVE BEHAVIOR] (explaining that at best, current actuarial instruments are only moderately predictive, having "Receiver Operating Characteristic" curve statistics of about 0.70 , or correlations of 0.30 ). Even with the best assessment instrument, the VRAG, only $55 \%$ of the individuals scoring as high risks actually recidivated compared with $19 \%$ recidivism in the low scoring group. See John Monahan, Violence Risk Assessment: Scientific Validity and Evidentiary Admissibility, 57 WASH. \& LEE L. REV. 901, 906-08 (2000).

6. For a more in-depth examination and appraisal of each of these instruments, see generally Erica Beecher-Monas \& Edgar Garcia-Rill, Chaos at the Edge of Danger: Predicting Violent Behavior in a Post-Daubert World, 24 CARDOZO L. REV. 1845 (2003). The current article retraces much of the discussion in Chaos, expanding on the danger of using behavioral genetics research and its findings to predict future dangerous behavior, including the threat to the moral authority of law.

7. See, e.g., Caroline M. Mee \& Harold V. Hall, Risky Business: Assessing Danger in Hawai' $i, 24$ U. HAW. L. REV. 63, 63 (2001) ("[D]angerousness prediction has heretofore been rudimentary and inaccurate, relying on clinical judgment rather than on objective measures."). Even when actuarial risk assessment is used, the results, while better than clinical predictions, are only moderately predictive. See, e.g., Malamuth et al., supra note 5.

8. The Human Genome Project refers to the international, thirteen-year research that sought to identify and determine the sequences of the genes and base-pairs making up human DNA. See, e.g., 
influence behavior.9 Scandinavian studies of adopted twins are widely touted as supporting the role of genes in crime..$^{10}$ That the cycle of violence is repeated across generations is common knowledge. ${ }^{11}$ Recently, alleles of specific genes, like those transcribing for monoamine oxidase A (MAOA), have been identified and linked with propensities to violence. ${ }^{12}$ Should adding genetic information to the mix not produce more accurate predictions of future dangerousness?

This question must be answered with a qualified yes and no. First, there is unfortunate history in this regard, and while we might wish to put the bad old days behind us, the shocking absence of scientific scrutiny for eugenics assertions has managed to persist in the astonishing failure of courts and legislatures to examine the scientific validity of expert future dangerousness predictions. ${ }^{13}$ Throwing away the key when someone has committed a grisly crime is an alltoo-human response to the specter of tragedy and nasty headlines. But it is precisely to counter such responses that we have the rule of law. Inquiry into the relevance and reliability of proffered evidence is a foundational aspect of this process.

Human Genome Project Information, http://www.ornl.gov/sci/techresources/Human_Genome/ project/hgl.shtml (last visited Feb. 4, 2006). The completed human genome sequence is estimated to consist of 20,000 to 25,000 protein-coding genes. See International Human Genome Sequencing Consortium, Finishing the Euchromatic Sequence of the Human Genome, 431 NATURE 931 (2004) (reporting the results of the project).

9. See, e.g., Richard P. Ebstein et al., Behavioral Genetics, Genomics, and Personality, in Behavioral Genetics In THE Postgenomic ERA 365, 380 (Robert Plomin et al. eds., 2003) ("[T]he importance of genetic factors in determining human temperament has been recognized for two decades."); Patrick Bateson, The Corpse of a Wearisome Debate, 297 SCIENCE 2212, 2212 (2002) (reviewing Stephen Pinker, The Blank Slate: The Modern Denial of Human Nature (2002)) ("[T]he center of th[e] academic debate is not about whether genes influence behavior but rather how they do so.").

10. See, e.g., Debra NiEhofF, The Biology of Violence: How Understanding THE BRAIN, BeHAVIOR, AND ENVIRONMENT CAN BREAK THE ViCIOUS CIRClE OF AGgRESSION 238 (1999) ("[T]win and adoption data favor a role for genetic influences [in crime]... . [W]hen concordance rates for violent crime were extracted from the Scandinavian data, none of the studies made a very convincing case for an appreciable genetic influence on violence."); MATT RIDLEY, THE AGILE GENE 19-20 (2004) (noting that twin studies demonstrate that "personality is about as heritable as body weight.").

11. See, e.g., NAT'L InST. OF JUST., THE CYCLE OF ViOLENCE REVISITED (1996), available at http://www.ncjrs.org/pdffiles/cyclepre.pdf (studying 1575 subjects over a twenty-six-year period, and concluding that abused and neglected children were twice as likely to be arrested as juveniles as children without such a history, and more likely to be arrested for a violent offense).

12. MAOA regulates neurotransmitters such as serotonin, dopamine, and epinephrine, and has been associated with psychopathy, childhood hyperactivity, childhood aggression, impulsivity, and substance abuse. See Grant T. Harris et al., The Construct of Psychopathy, 28 CRIME \& JUST. 197, 224 (2001) ("[F]indings on all of these laboratory-based theories of psychopathy often seem somewhat ephemeral."). See also Avshalom Caspi et al., Role of Genotype in the Cycle of Violence in Maltreated Children, 297 SCIENCE 851, 851-53 (2002) (studying 442 men in New Zealand for differences in MAOA activity alleles and correlating these differences with maltreatment in childhood and subsequent violent behavior). The results demonstrated that the high activity form of the gene did not manifest in violent propensities even if the men had been mistreated as boys, while those with the low-active form of the gene who had been mistreated committed four times as many rapes, assaults, and robberies as the average. $I d$.

13. See, e.g., Erica Beecher-Monas, The Epistemology of Prediction: Future Dangerousness Testimony and Intellectual Due Process, 60 WASH. \& LEE L. REV. 353, 359 (2003) (discussing the courts' failure to examine the scientific validity of future dangerousness testimony). 
Second, although information from the biology of violence, including genomics, could vastly improve the way predictions are made, such information must be tested, scrutinized, and properly limited so that the promise of science is not once again perverted into the cynicism of political expediency. This leads to the third point: Although genes may constrain or influence behavior, they do so only in concert with each other and with the environment both internal and external to the organism carrying the genes.

Initially, future dangerousness predictions were based on mostly wrong and mostly unchallenged notions of heredity ${ }^{14}$ and acted upon mostly in such "preventive" measures as mass sterilizations ${ }^{15}$ indeterminate sentencing, and ethnically biased immigration laws. ${ }^{16}$ Because genes were considered strictly deterministic, these hereditarian notions of crime control were coupled with the idea of diminished responsibility. ${ }^{17}$ Thus, at the same time legislatures were enacting these preventive crime control measures, Clarence Darrow managed to save his clients Nathan Leopold and Richard Loeb from the death penalty by arguing that they were the "product of heredity." 18 These twin themes linking genetics to crime prevention and exoneration have resurfaced with the massive attention drawn to the Human Genome Project. Behavioral genetics has been heralded as the future of criminal justice..$^{19}$

14. They were also based on fallacious notions about genetic differences among ethnic groups. See, e.g., John Tooby \& Leda Cosmides, On the Universality of Human Nature and the Uniqueness of the Individual: The Role of Genetics and Adaptation, 58 J. PERSONALITY 1, 34-35 (1990), in which the authors explain that modern molecular genetics have shown no basis for believing that "each ethnic group has a set of genes shared by members of the group, but not shared by others." Rather, the genetic difference between individuals of the same ethnic group is much larger than the genetic difference between groups: "within-group variance is 12 times greater than the between-group variance." From an evolutionary standpoint, this is consistent with the pathogen theory of sexual recombination: because people "catch diseases from their neighbors ... it is important to be genetically different from them; such selection ... promot[es] local within-group diversity and reduc[es] intergroup diversity.... Although there is a sea of genetic diversity (measured at the protein level), it is a well-mixed sea." Id.

15. See, e.g., Charles C. Mann, Behavioral Genetics in Transition, 264 SCIENCE 1686, 1686 (1994) ("By 1930, 24 states had enacted laws to sterilize the 'feeble-minded," who were believed to be responsible for a degenerate society and the crime that was rampant within it).

16. See id. at 1686 (noting that Calvin Coolidge signed the Immigration Restriction Act in 1924, aimed at protecting the United States from "supposedly inferior Latin and Slavic genes"); see also Michael Willrich, The Two Percent Solution: Eugenic Jurisprudence and the Socialization of American Law, 1900-1930, 16 LAW \& HIST. REV. 63, 84 (1998) (remarking on the "link between heredity, feeblemindedness and criminality" as the focus of prison and mental institution reformers in the early part of the twentieth century).

17. See, e.g., Albert W. Alschuler, The Changing Purposes of Criminal Punishment: A Retrospective on the Past Century and Some Thoughts About the Next, 70 U. CHI. L. REV.1, 3-5 (2003) (discussing the influence of Darwinism on criminal theory).

18. Clarence Darrow, The Crime of Compulsion, Address of Case Summation Before John R. Caverly, Chief Justice of the Criminal Court of Cook County (Aug. 22, 1924), in ATTORNEY FOR THE DAMNED: Clarence DARRow In THE COURTROOM 65-66 (Arthur Weinberg ed., Univ. of Chi. Press 1989) (1957).

19. See, e.g., Lori B. Andrews, Predicting and Punishing Antisocial Acts: How the Criminal Justice System Might Use Behavioral Genetics, in BeHAVIORAL Genetics: THE Clash OF Culture AND BIOLOGY 134-35 (Ronald A. Carson \& Mark A. Rothstein eds., 1999) (suggesting that in the future, the state might consider genes "thought to be associated with precursors to criminal behavior"); David 
The questions now facing social policymakers are whether and how to use these scientific advances so as to avoid the pitfalls of eugenics. Involuntary sterilization statutes may have been repealed, ${ }^{20}$ determinate sentencing guidelines may have imposed some uniformity on punishment, ${ }^{21}$ and immigration laws may no longer retain ethnically biased language; nonetheless, the criminal justice system's reliance on future dangerousness predictions has increased dramatically, and without scientific scrutiny. Future dangerousness predictions are required in a wide range of proceedings, including civil commitments, juvenile adjudications, bail hearings, competency hearings, insanity determinations, and sentencing, yet "dangerousness prediction has heretofore been rudimentary and inaccurate, relying on clinical judgment rather than on objective measures." 22

Wasserman, Is There Value in Identifying Individual Genetic Predispositions to Violence?, 32 J.L. MED. \& ETHICS 24, 24 (2004) (forecasting the expanded use of behavioral genetics in crime control); Lindsy A. Elkins, Note, Five-Foot Two With Eyes of Blue: Physical Profiling and the Prospect of a GeneticsBased Criminal Justice System, 17 Notre DAme J.L. ETHICs \& PUB. POL'y 269, 271 (2003) ("DNA analysis could serve as an antidote to racial profiling [and could explore the] broader implications of using genetic research."); Rhonda J. Yen, Tourette's Syndrome: A Case Example for Mandatory Genetic Regulation of Behavioral Disorders, 27 LAW \& PSYCHOL. REV. 29, 29 ("[T]he vision of Gattaca [a 1997 movie depicting a society driven by genetic engineering] is closer than many of us realize."); Kathy Hudson, Keynote Address, The Human Genome Project, DNA Science and the Law: The American Legal System's Response to Breakthroughs in Genetic Science, 51 AM. U. L. REV. 431, 443-44 (2002) (forecasting changes when behavioral genetics enters into the criminal justice system in terms of defenses and predisposition to commit crime); Nicole Hahn Rafter, Seeing and Believing: Images of Heredity in Biological Theories of Crime, 67 BROOK. L. REV. 71, 98 (2001) ("Pop criminologists may soon come up with recommendations for genetic engineering."); Jasmine A. Tehrani \& Sarnoff A. Mednick, Genetic Factors and Criminal Behavior, 64 FED. PROBATION 24, 26 (2000) ("[C]rime prevention efforts may be most effective when all risk factors, social and genetic, are evaluated."); Nikolas Rose, The Biology of Culpability, Pathological Identification and Crime Control in a Biological Culture, 4 THEORETICAL CRIMINology 5 (2000); Bettyann Kevles \& Daniel J. Kevles, Scapegoat Biology: As Violence Continues to Ravage Our Society, Researchers are Raising Hopes that Science Alone Can Save Us From Our Worst Natures-Again, DISCOVER, Oct. 1997, at 58, 59-60 ("Crime joins ... many aspects of human life for which it can be claimed that biology is destiny.").

20. The Virginia statute allowing forced sterilization of "mental defectives," upheld in Buck v. Bell, 274 U.S. 200 (1927), was repealed in 1974. 1974 Va. Acts ch. 296. However, a voluntary sterilization statute mandating castration as a condition of parole for repeat sex offenders was enacted in California in 1996. CAL. PENAL CODE $\S 645$ (West 2005). Florida, Georgia, and Montana have similar statutes. See Fla. Stat. ANN. § 794.0235 (West 1997); GA. CodE ANN. § 49-9-44.2 (West 1997); MonT. CodE ANN. § 45-5-512 (1997).

21. See United States v. Booker, 125 S. Ct. 738 (2005) (ruling that sentencing guidelines must be merely discretionary). However, the post-Booker consequences for determinate sentencing are anybody's guess.

22. Mee \& Hall, supra note 7, at 63. Indeed, predictions of future dangerousness (on which the death penalty, sex offender registration and post-sentence commitment, to name just a few, are based) have become pervasive in the criminal justice system. For example, Deborah Denno ascribes the "dramatic surge in sexual psychopath legislation" to the "medicalization of deviance." Deborah Denno, Life Before the Modern Sex Offender Statutes, 92 Nw. U. L. REV. 1317, 1320 (1998). It is not a far leap from "medicalization" to assuming a genetic basis for sexually deviant behavior. See Lori B. Andrews, Predicting and Punishing Antisocial Acts, in BeHAVIORAl Genetics: THE Clash of Culture And Biology 116, 134 (Ronald A. Carson \& Mark A. Rothstein eds., 1999) (noting that because racial prejudice affects surveillance, arrests, and sentencing, "it is often taken for granted that [blacks'] higher representation in arrests and in prison means they are more violence prone" without acknowledging the skewed sampling). For example, Professor Andrews points out that "[p]regnant white women are slightly more likely to abuse drugs than pregnant black women, but pregnant black women are 9.58 times as likely to be reported for substance abuse during pregnancy." Id. 
On the other hand, apart from Clarence Darrow's clients, defendants who have attempted to use the idea of innate propensities to negate individual responsibility have met with great resistance. Unless the accused independently meets the criteria for legal insanity, criminal defenses built on behavioral genetics have been overwhelmingly defeated. ${ }^{23}$ Putting aside for a moment the question whether the courts were correct about the poor science behind these assertions denying culpability due to genetic predispositions, it appears odd, as a practical matter, that the same courts rely on predictions of dangerousness that are even less scientific.

Part II of this article discusses and critiques the courts' use of future dangerousness predictions in sentencing and post-sentence commitment proceedings for capital murderers and sex offenders and in community notification requirements for sex offenders. Part III addresses the growth of knowledge about the biology of violence and sexual violence, and questions whether such information could be incorporated into actuarial instruments that might more reliably form the basis for sentencing and post-sentencing determinations. Part IV examines the problems of predicting violence based on genetic information. Part $\mathrm{V}$ concludes that the courts' insistence on future dangerousness predictions is ill-conceived for both legal and scientific reasons. Nevertheless, in the face of their unwillingness to abandon such predictions, the courts must at a minimum insist on the most accurate information available, and that information includes the role of genes in the biology of violence.

II

\section{FUTURE DANGEROUSNESS IN THE COURTS}

Predictions of future dangerousness are widely admissible without any judicial inquiry into their scientific validity. ${ }^{24}$ This is astonishing in a system that embraces the tenet that only facts having rational probative value should be

23. As soon as studies linking XYY chromosomal abnormalities with criminal propensities became available, defense attorneys argued that their clients should be exonerated. In the United States, the four cases that attempted such a genetic defense were unsuccessful. See State v. Roberts, 544 P.2d 754 (Wash. Ct. App. 1976) (affirming trial court's denial of genetic testing because of the uncertain causal connection between XYY and criminal conduct); People v. Yukl, 372 N.Y.S.2d 313 (N.Y. Sup. Ct. 1975) (refusing to order genetic testing or to permit the defendant's father to pay for genetic testing because the evidence of a genetic link to violence was not reliably established); People v. Tanner, 91 Cal. Rptr. 656 (Cal. Ct. App. 1970) (finding that neither the link to aggressive behavior nor a chromosomal contribution to legal insanity were established); Millard v. State, 261 A.2d 227 (Md. Ct. Spec. App. 1970) (upholding trial court's refusal to submit the genetic issue to the jury because the expert failed to demonstrate a link between the XYY condition and the legal definition of insanity). An attempt to obtain expert testimony to mitigate the sentence of a capital murder defendant on the basis of MAOA gene abnormality has also been unsuccessful. See Turpin v. Mobley, 502 S.E.2d 458 (Ga. 1998) (finding no ineffective assistance of counsel in rejecting defendant's father's offer to pay for genetic testing for MAOA deficiency analysis after the trial court refused to pay for it).

24. See Scherr, supra note 3. 
admissible in the search for truth. ${ }^{25}$ Yet judges continue to admit predictions that no one seriously argues can meet these standards. If the test by which an evidentiary practice should be judged is whether it increases the likelihood that the truth, defined as correspondence to the real world, will be attained, expert future dangerousness testimony fails to make the grade. ${ }^{26}$

Basic rule of law precepts appear to be tossed out with the bathwater when it comes to gruesome murders and violent sex offenses. People deemed to be at risk for sexually violent recidivism are not only singled out for involuntary postsentence commitment, community registration, or lifetime parole, but the determination of their guilt for sexual offenses can be based on evidence of past crimes, which would be impermissible "character evidence" for other felony defendants. ${ }^{27}$ The justification for this disparate treatment is that sex crimes are different from other crimes of violence and that sex offenders are more incorrigible and less likely to be deterred by the threat of incarceration. ${ }^{28}$ In sentenc-

25. See, e.g., FED. R. EVID. 402 \& 403 (requiring both relevance and probativity in order for evidence to be admissible).

26. Beecher-Monas \& Garcia-Rill, supra note 6, at 1856-60 (explaining that clinical future dangerousness testimony cannot meet the standards of Daubert v. Merrell Dow Pharmaceuticals, Inc., 509 U.S. 579 (1993), and Gen. Elec. Co. v. Joiner, 522 U.S. 136, 140 (1997), because it is entirely subjective, ungrounded in empirical data, and therefore unfalsifiable; has been overwhelmingly castigated by the profession, and thus fails peer review, publication, and general acceptance; has no standards for its methodology; and cannot meet the requirements for an acceptable error rate). We are not, as Professor Scherr contends, seeking a "bare relevance" standard. See Scherr, supra note 3, at 3 (arguing that because future dangerousness testimony fills a perceived need of the courts it is justified under Daubert's "fit" requirement). Rather, we contend that with respect to expert testimony, relevance under Daubert and rule of law principles consists of two prongs: reliability (scientific validity); and a logical tendency to prove or disprove an issue in the case. Beecher-Monas \& Garcia-Rill, supra note 6. Sometimes the concept of "fit" is called "materiality," but it is considered to be one of the generative principles of the law of evidence. See Robert P. Burns, Notes on the Future of Evidence Law, 74 TEMP. L. REV. 69, 70 (2001) (noting that the generative principle of materiality, now subsumed under the relevance requirement, permits into evidence only evidence of consequence to the "legitimate determination of the action"). Contrary to the Court's contention in Barefoot v. Estelle, the adversary process cannot be trusted "to sort out the reliable from the unreliable evidence and opinion about future dangerousness." 463 U.S. 880, 901 (1983). Rather, as the Supreme Court explained in Daubert v. Merrell Dow Pharmaceuticals, Inc., the requirement that expert testimony be helpful to the jury, "supported by appropriate validation - that is, 'good grounds,' based upon what is known," is a condition of relevance. 509 U.S. 579, 590-91 (1993). And relevance is not "merely" a matter of evidentiary rules; it is a constitutional minimum, "a requirement of due process and a fundamental fairness requirement of the rule of law." Erica Beecher-Monas, The Epistemology of Prediction: Future Dangerousness Testimony and Intellectual Due Process, 60 WASH. \& LEE L. REV 353, 361 (2003).

27. Compare FED. R. EVID. 413 (stating evidence of similar crimes in sexual assault cases is admissible) and FED. R. EVID. 414 (permitting evidence of similar crimes in molestation cases) (enacted by Congress as part of the Violent Crime Control and Law Enforcement Act of 1994; effective July 9, 1995) with FED. R. EVID. 404(b) ("Evidence of other crimes, wrongs, or acts is not admissible to prove the character of a person in order to show action in conformity therewith.").

28. There is little evidence for this, however, and Congress cited none in passing the Violent Crime Control and Law Enforcement Act of 1994. For example, in Seling v. Young, regarding a postsentence, sexual offender commitment, the Supreme Court held that even when confinement conditions raised serious concern, release from commitment is unavailable. 531 U.S. 250 (2001). The Court rejected ex post facto and double jeopardy claims, although it left open the possibility that due process claims might be available. Id. at 263. Eric Janus argues that the constitutionality of sexual predator commitments is premised on that of only the most dangerous, a premise that is "dubious because of the limitations in our ability to predict dangerousness." Eric S. Janus, Closing Pandora's Box: Sexual Predators and the Politics of Sexual Violence, 34 Seton Hall L. Rev. 1233, 1237 (2004). Professor 
ing sex offenders and capital murderers, as well as in the post-sentencing disposition of sex offenders, predictions of future dangerousness are rampant, although generations of scientists have explained that such predictions cannot meet the standards of science. As argued elsewhere, ${ }^{29}$ this is a far cry from the truth-generating methodologies supposedly fundamental to due process, and the movement away from requiring a modicum of credibility is counter to what goes on in civil trials, in which experts must demonstrate the reliability of their testimony. ${ }^{30}$

Predicting future dangerousness has become important as the criminal justice system has changed its focus from punishment to preventing violent recidivism. $^{31}$ Although "most offenders have only one recorded violent offense" ${ }^{, 32}$ and only a small proportion of criminal offenses are violent, the focus of criminal justice has shifted from punishment to deterrence through incarceration, civil commitment, or death. ${ }^{33}$ For specific sexual offenders, not only are sentences vastly increased for second and third offenses, but sexually violent predator statutes provide for indefinite post-sentence civil commitment. ${ }^{34}$ These statutes-as well as sexual offender registration laws, three-strikes laws, which authorize life sentences for repeat offenders, and laws that lower the age at which juveniles may be tried as adults - are all based on the notion of preventing future crimes.

Janus considers the other bases for finding these commitments constitutional—-that somehow this small group of offenders is "different" from normal people because they are mentally disordered, and that confinement would be only for the period of treatment-equally flawed. Id. at 1236 .

29. Beecher-Monas \& Garcia-Rill, supra note 6.

30. See, e.g., Julie G. Shoop, Judges are Gaining Confidence in Assessing Expert Evidence, Study Finds, 38 TRIAL 92, 92 (2002) (reporting findings by the Rand Institute for Civil Justice that Daubert has had a significant impact on the admissibility of expert testimony in civil trials: judges' close scrutiny of relevance and reliability has resulted in a dramatic increase in the percentage of expert testimony excluded in products liability trials and in a consequential surge in summary judgments against the plaintiffs). This increased scrutiny of scientific evidence has not affected criminal trials nearly so dramatically. See, e.g., Paul C. Gianelli, Scientific Evidence in Civil and Criminal Cases, 33 ARIZ. ST. L.J. 103, 119 (2001) (discussing myriad instances in which criminal judges fail to take Daubert seriously); Erica Beecher-Monas, Blinded by Science: How Judges Avoid the Science in Scientific Evidence, 71 TEMP. L. REV. 55, 78-82 (1998).

31. See Christopher Slobogin, A Jurisprudence of Dangerousness, 98 NW. U. L. REV. 1, 62 (2003) ("Preventive detention is a pervasive, routine occurrence in our society."); $c f$. Stephen J. Morse, Preventive Confinement of Dangerous Offenders, 32 J.L. MED. \& ETHICS 56, 56 (2004) ("[P] ure preventive detention is more common than we usually assume, but . . . this practice violates fundamental assumptions concerning liberty under the American constitutional regime.").

32. David P. Farrington, Predictors, Causes, and Correlates of Male Youth Violence, 24 CRIME \& JUST. 421, 434 (1998) (citing studies).

33. Paul H. Robinson, Punishing Dangerousness: Cloaking Preventive Detention as Criminal Justice, 114 HARV. L. REV. 1429, 1450 n.77 (2001) (noting the shift to preventing future violations and observing that most felony offenders are not convicted of a subsequent offense).

34. See, e.g., VA. CODE ANN. § 37.1-900 (2005).

35. See Robinson, supra note 33, at 1432 (arguing this approach perverts the justice system). In addition to three-strikes laws, a number of states have enacted two-strikes laws with enhanced sentences for violent sexual offenders. See Roxane Lieb et al., Sexual Predators and Social Policy, 23 CRIME \& JUST. 43, 70 (1998) (observing a "trend toward sentences that incapacitate offenders" and noting increased sentences for sex offenders). Experts estimate that two-thirds of offenders affected by 
In capital sentencing, for example, Texas requires the jury to decide "whether there is a probability that the defendant would commit criminal acts of violence that would constitute a continuing threat to society." ${ }^{36}$ Similarly, the Virginia sentencing guidelines use a sex offender risk assessment instrument to recommend that judges consider increased sentences; for nearly half of all sex offenders, this results in a modification upwards. ${ }^{37}$ For the top scorers, it can result in trebled sentences. ${ }^{38}$

Sexually violent predator statutes similarly rely on predictions of dangerousness to extend confinement, even beyond terms served. ${ }^{39}$ Legislatures in sixteen states and the District of Columbia have enacted sexually violent predator laws that civilly commit sexual offenders who have already served their criminal sentences to further indefinite incarceration..$^{40}$ A common definition of a sexual

the three-strikes law in California are non-violent offenders. FRANKLIN E. ZIMRING \& GORDON HAWKINS, CRIME IS NOT THE PROBLEM: LETHAL VIOLENCE IN AMERICA 182 (1997).

36. TX. CODE CRIM. PROC. ANN. § 37.071 (Vernon 1996). Virginia also explicitly requires a finding of future dangerousness in capital sentencing proceedings. VA. CODE ANN. § 19.2-264.2-4 (2004). Even when jurors are not explicitly required to consider future dangerousness, studies of capital jurors have shown that "discussion of the defendant's dangerousness occupies a large portion of the time jurors spend deliberating on whether a death sentence is appropriate, regardless of how or whether this information is included at any point during the sentencing phase." Aletha M. Claussen-Schulz et al., Dangerousness, Risk Assessment, and Capital Sentencing, 10 PsYCHOL. PuB. POL'Y \& L. 471, 480 (2004).

37. The Virginia guidelines present the judge with "a midpoint recommendation" for each defendant and a range of sentencing options, in which the high end is increased for the riskiest group of offenders. Richard P. Kern \& Meredith Farrar-Owens, Sentencing Guidelines with Integrated Offender Risk Assessment, 16 FED. SENT. R. 165, 2004 WL 2189126, at *5. The factors used for this instrument are: age at the time of conviction (paradoxically, you get a worse sentence for being young); prior history of sex offense arrests; criminal record; relationship with the victim; victim's age; whether there was penetration (or attempted penetration); whether the defendant had received treatment; and education level. Id. There was apparently no testing of this instrument outside the Virginia Sentencing Commission, and it was neither peer-reviewed nor published in scientific journals before being implemented. Id. Although two cases have challenged the use of the sex offender instrument, neither was successful. See Brooks v. Commonwealth, No. 2540-02-3, 2004 WL 136090 (Va. Ct. App. Jan. 28, 2004) (upholding constitutionality of guidelines system because they were discretionary with the judge); Lutrell v. Virginia, No. 2092-02-4 (Va. Ct. App. Feb. 17, 2004) (rejecting appeal based on unreliability of instrument because Virginia exempts from appeal judicial use of sentencing guidelines).

38. See Kern \& Farrar-Owens, supra note 37 , at $* 6$ (noting that $48 \%$ of rapists and $41 \%$ of felony sex assault offenders received an upward modification, although only $3 \%$ of rapists and $2 \%$ of sexual assault offenders received the highest increase, which tripled their possible sentence).

39. Most state statutes concerning sexually violent predators require a finding of future dangerousness, plus current mental illness. See, e.g., WASH. REV. CODE § 71.09.010 (1990) (civil commitment proceedings require a determination of future danger and mental illness). The Supreme Court upheld the constitutionality of such indefinite post-sentence commitments in Kansas v. Hendricks, finding both that the civil commitment of sexual predators does not constitute punishment and that states may confine individuals whose mental abnormality makes them likely to commit future offenses. 521 U.S. 346, 346-47 (1997).

40. These states include: Arizona, ARIZ. Rev. STAT. ANN. §§ 36-3701-3717 (2003); California, CAL. Welf. \& INST. CODE $\S \S 6600-09.3$ (West 1998 \& Supp. 2005); Florida, FlA. STAT. ANN. §§ 394.910-.931 (West 2002 \& Supp. 2005); Illinois, 725 ILL. COMP. STAT. 207/1-99 (2002 \& Supp. 2004); Iowa, IOwA CODE ANN. §§ 229A.1-.16 (West Supp. 2005); Kansas, KAN. STAT. ANN. § 59-29a02 (2004 \& Supp. 2005); Massachusetts, MASS. ANN. LAws ch. 123A (LexisNexis 2003 \& Supp. 2005); Minnesota, Minn. Stat. AnN. § 253B.02 (West 2003); Missouri, Mo. AnN. STAT. § 632.480 (West 2000); New Jersey, N.J. STAT. ANN. § 30:4-27.24 (West Supp. 2005); Oregon, OR. REV. STAT. § 426.005 (1998); South Carolina, S.C. CodE ANN. § 44-48-10 (1998); Texas, TEX. HeAlth \& SAFETY CodE 
predator is someone who has committed a crime of sexual violence and has a mental or personality disorder that makes future acts of sexual violence likely. ${ }^{41}$ Although definitions of sexual predator may vary by statute, they all require findings that future acts of sexual violence are likely. ${ }^{42}$ Clinical predictions alone, or in combination with actuarial risk assessment instruments, have been widely accepted as adequately reliable for the severe deprivations of liberty authorized by the violent sexual predator statutes. ${ }^{43}$

Community notification statutes, the first of which was Megan's Law, are also based on predicting the dangerousness of sex offenders. ${ }^{44}$ Selective community notification is now commonplace for released sex offenders. In New Jersey, and most other states, offenders are scaled on a risk assessment instrument and entitled to a hearing to evaluate their dangerousness. ${ }^{45}$ If the offenders are deemed to be a danger to the community, they must register information such as their address with a sexual offender registry that is accessible by the public, leading to dire consequences for their ability to obtain housing, employment, and other resources.

While future dangerousness is often explicitly a factor in determining the sentence for violent murders and sex offenses, some courts are predicting future criminality even for nonviolent offenders. In Virginia, for example, two kinds

ANN. §§ 841.001-.002 (Vernon 1999); Virginia, VA. CODE. ANN. § 37.2-900 (2005); Washington, WASH. REV. CODE ANN. § 71.09.010 (West 2002 \& Supp. 2005); Wisconsin, Wis. STAT. § 980.01 (1998).

41. See, e.g., KAn. StAT. AnN. § 59-29a01 (2004 \& Supp. 2005). Some states, like Minnesota, require that the victim be a stranger, which virtually guarantees that the most prevalent, and arguably the most devastating, form of sexual offense-that which occurs within the family-remains unaddressed. See, e.g., Eric S. Janus, Minnesota's Sex Offender Commitment Program: Would an Empirically-Based Prevention Policy be More Effective?, 29 WM. MITCHELL L. REV. 1083, 1087 (2003) ("[T]he overwhelming majority of sexual crimes... [are] committed by acquaintances and intimates of the victims.").

42. See John M. Fabian, Examining Our Approach to Sex Offenders \& the Law, Kansas v. Hendricks, Crane and Beyond: "Mental Abnormality," and "Sexual Dangerousness": Volitional vs. Emotional Abnormality and the Debate Between Community Safety and Civil Liberties, 29 WM. MiTCHELL L. REV. 1367, 1369 (2003) ("The term 'sexual predator' [is] usually applied to offenders who offend against strangers, have multiple victims, have prior sexual offenses, are sexually deviant and suffer from paraphilias such as pedophilia, commit violent offenses, and may have exhibited other antisocial and criminal behaviors.").

43. See, e.g., In re Commitment of R.S., 773 A.2d 72 (N.J. Super. Ct. App. Div. 2001) (upholding use of actuarial instruments to assess future dangerousness); Johnson v. Missouri, 2001 WL 527494 (Mo. Ct. App. May 18, 2001) (finding that expert testimony was necessary to determine that a defendant incarcerated since his teens had a mental abnormality that made him likely to commit sexual violence); In re Blodgett, 510 N.W.2d 910, 917 n.15 (Minn. 1994) (giving broad deference to expert predictions of future dangerousness); State v. Post, 541 N.W.2d 115, 132 (Wis. 1995) (rejecting challenge based on impossibility of prediction).

44. The New Jersey legislature in 1994 adopted a series of measures under the name Megan's Law, including extending prison terms, involuntary civil commitment, lifetime parole supervision, and mandatory DNA sampling for identification. N.J. STAT. ANN. 2C §§ 7-1-7-11 (West Supp. 2005). The registration provisions require sex offender registration with law enforcement and community notification. Id.

45. In re Registrant G.B., 685 A.2d 1252, 1260-61 (N.J. 1996). 
of risk assessment instruments are being used for sentencing determinations. ${ }^{46}$ In addition to the violent offender instrument, the nonviolent offender risk assessment instrument was developed in response to overcrowding of Virginia's prisons and is used to determine who should receive a jail sentence and who could be placed on probation. ${ }^{47}$

\section{A. Gatekeeping Dilemmas}

In a trio of evidentiary cases, Daubert v. Merrell Dow Pharmaceuticals, Inc. ${ }^{48}$ General Electric Company v. Joiner, ${ }^{49}$ and Kumho Tire Company v. Carmichael, ${ }^{50}$ the Supreme Court demanded that judges examine the empirical foundations of expert assertions made in their courts to ensure that the underlying data is sound. These cases command that judges admit into evidence only expert testimony that passes scientific muster, testimony that at a minimum meets the standards and methods of science. ${ }^{51}$

No such trustworthiness inquiry is compelled regarding expert testimony about the defendant's future dangerousness, ${ }^{52}$ whether that testimony is presented in a capital sentencing hearing or in sexual offender commitment proceedings. In capital sentencing, this relaxed evidentiary standard for expert testimony is due, in large part, to the Supreme Court's holding in Barefoot v. Estelle $^{53}$ that expert testimony as to a defendant's future dangerousness is constitutional. In sexual offender commitment proceedings, the lower standard rests on Kansas v. Hendricks, ${ }^{54}$ in which Court upheld a state statute that permitted indefinite commitments of sexual offenders based on future dangerousness tes-

46. See Kern \& Farrar-Owens, supra note 37, at *8 ("Virginia is the only structured sentencing guidelines system in the nation that has formally integrated offender risk assessment tools grounded in criminological research.").

47. See Emily Bazelon, Sentencing by the Numbers, N.Y. TIMES MAG., Jan. 2, 2005, at 18-19 (discussing the Virginia sentencing program). These tables are based on factors such as adult and juvenile criminal records, gender, age, employment, and marital status. Id. Judges use a 71-point scale of risk assessment employing these factors to aid in sentencing. Id. A score of 35 or less means the defendant is eligible for house arrest or probation. Id. If a defendant receives a score of 35 or more, the recommendation is jail time. Id. The Virginia sentencing commission's chair claims that in testing the scale on prisoners who had been released five years previously, the table was accurate in three out of four cases. Id.

48. 509 U.S. 579 (1993).

49. 522 U.S. 136, 140 (1997) (reiterating the trial judge's mandate to review testimony for scientific validity and "fit").

50. 526 U.S. 137 (1999) (extending the scope of the Daubert inquiry to technical evidence).

51. Notably, one-third of the prisoners exonerated by the Actual Innocence Project had been convicted on the basis of "tainted or fraudulent science." JIM DWYER ET AL., ACTUAL INNOCENCE: FIVE DAYS TO EXECUTION AND OTHER DISPATCHES FROM THE WRONGLY CONVICTED 246 (2000).

52. $C f$. Morse, supra note 31, at 59 ("The incentive structure predisposes the gatekeepers in cases involving danger to over-predict.").

53. 463 U.S. 880 (1983) (upholding the admissibility of expert testimony about future dangerousness, even when stated in response to hypothetical questions based upon controverted facts). Notably, no opinion in the Daubert trilogy referred to Barefoot. Kumho, however, did castigate astrology as unscientific. 526 U.S. at 151.

54. 521 U.S. 346 (1997). 
timony. And in Kansas v. Crane ${ }^{55}$ the Court revisited the Kansas Act, once more failing to address the problematic nature of expert future dangerousness testimony. ${ }^{56}$ None of these cases has required the trustworthiness demonstration that rule of law principles, the Daubert trio, and the Federal Rules of Evidence appear to require of expert testimony under any other circumstance. One is entitled to be cynical about such rules when sentences of death, incarceration, and preventive detention can be based on predictions that the courts acknowledge to be scientifically flimsy.

\section{B. Gatekeeping under Daubert}

Explicitly addressing the Federal Rules of Evidence, Daubert held that scientific validity and the "fit" of expert testimony to the facts in the case are questions of reliability and relevance..$^{57}$ Four "general observations" guide the inquiry into scientific validity: (1) testability; (2) peer review and publication; (3) the existence of methodological standards, including the error rate of the methodology; and (4) general acceptance. ${ }^{58}$ The overall goal of these flexible guidelines is to evaluate expert testimony by the standards scientists themselves use to critique each other's work. ${ }^{59}$ In Joiner and Kumho, the Court subsequently reiterated the Daubert standards, expounding on its notion of "fit," and explaining that not only do judges have to evaluate the scientific validity of testimony based on the traditional "hard" sciences, but that they must also evaluate the validity of expert testimony based on what are often referred to as the "soft" sciences, such as psychology. ${ }^{60}$ Congress subsequently amended the Federal Rules of Evidence to codify these cases. ${ }^{61}$

These changes in evaluating the admissibility of expert testimony under the Federal Rules of Evidence have profoundly affected not only the federal courts, but state courts as well. ${ }^{62}$ Even jurisdictions that eschew the Daubert standard in favor of the "general acceptance" standard of Frye v. United States ${ }^{63}$ are be-

55. 534 U.S. 407 (2002).

56. Id. at 411-12. In Kansas v. Hendricks, the Court had relied on Hendricks' testimony that the only way he could control his impulses to molest children was "to die." 521 U.S. at 355. Thus, Crane contended the state had to show an absence of control. The Supreme Court disagreed, holding a showing only of "serious difficulty in controlling dangerous behavior," rather than a complete absence of control, was necessary to meet constitutional standards. Crane, 534 U.S. at 408.

57. 509 U.S. 579, 590-91 (1993).

58. Id. at 593-94.

59. See id. at 580, 593 (characterizing the inquiry as a "flexible one").

60. See id. at 137 (addressing issue of expert's engineering testimony).

61. FED. R. EVID. 702.

62. For an article describing some of these changes, see generally Clark Hedger, Note, Daubert and the States: A Critical Analysis of Emerging Trends, 49 ST. LOUIS U. L.J. 177 (2004) (describing state court reactions to Daubert and FED. R. EVID. 702).

63. 293 F. 1013 (D.C. Cir. 1923). For over seventy years, the only scientific evidence admissible in court was that which purported to reflect a consensus of the relevant scientific community. This was the standard articulated in Frye, which explained that "while courts will go a long way in admitting expert testimony deduced from a well-recognized scientific principle or discovery, the thing from which 
ginning to insist that expert testimony meet standards of scientific validity. ${ }^{64}$ Thus, even in courts in which the Daubert standard is not followed, there is an increased awareness that whatever evidence is considered should be based on a sound empirical foundation. Such awareness supports the argument that Daubert's general principles of judicial screening for scientific validity should apply to all expert testimony. ${ }^{65}$

\section{Gatekeeping and Future Dangerousness}

\section{Barefoot v. Estelle}

At issue in Barefoot was the constitutionality of permitting psychiatrists to testify in a capital sentencing hearing about the defendant's future behavior, given that such predictions were shown to be wrong two out of three times. ${ }^{66}$ At the hearing, two psychiatrists testified that the defendant "would probably commit further acts of violence and represent a continuing threat to society, ${ }^{{ }^{67}}$ based on a hypothetical question about the crime and the defendant's conduct. ${ }^{68}$ The Court acknowledged the American Psychiatric Association's opposition to future dangerousness testimony because of its extreme unreliability ${ }^{69}$ but upheld its admissibility because disallowing such testimony would be like "disinvent[ing] the wheel." ${ }^{70}$ Reliability, then as now, was the touchstone for admissibility of evidence at sentencing. ${ }^{71}$ Nonetheless, the Court noted that the Association did not claim that psychiatrists were always wrong with respect to future dangerousness predictions-only that they were wrong more often than not.

the deduction is made must be sufficiently established to have gained general acceptance in the particular field in which it belongs." 293 F. at 1014.

64. See, e.g., Blum v. Merrell Dow Pharms., Inc., 705 A.2d 1314, 1323 (Pa. Super. Ct. 1997) (reviewing expert testimony under the Frye standard and addressing scientific validity).

65. Beecher-Monas \& Garcia-Rill, supra note 6.

66. See 463 U.S. 880, 899-902 (1983). An amicus brief by the American Psychiatric Association before the court explained that no one, including psychiatrists, can predict with any degree of reliability that an individual will commit other crimes in the future. Id. at 899. Some scholars argue that clinical predictions have improved since Barefoot, but even these scholars only contend a slightly better-thanchance record for clinical predictions. See Monahan, supra note 5.

67. Barefoot, 463 U.S. at 884.

68. The prosecutor's hypothetical asked the psychiatrists to assume a number of facts about the defendant: his conviction for five nonviolent criminal offenses, arrests for sexual offenses against children, a bad reputation in the eight communities the defendant had lived in over ten years, unemployment during the two months preceding the crime, drug use, boasting of plans to commit crimes to acquaintances, shooting a police officer without provocation from a distance of six inches, and acting as though there were nothing unusual after the crime. Brief for the American Psychiatric Association as Amicus Curiae Supporting Petitioner at 5, Barefoot v. Estelle, 463 U.S. 880 (1983) (No. 82-6080).

69. Barefoot, 463 U.S. at 904.

70. Id. at 896 .

71. See Flores v. Johnson, 210 F.3d 456, 464 n.10 (5th Cir. 2000) (Garza, J., concurring) ("[T]he cardinal concern of the rules of admissibility for expert testimony-reliability-is also the paramount concern in addressing the constitutionality of capital sentencing procedures."). 
The Supreme Court concluded the state could sentence the defendant to death based on scientifically questionable testimony because the state's evidentiary rules permitted such testimony. ${ }^{72}$ The Court distinguished its decision in Barefoot from scientific evidence cases in which testimony about future dangerousness had been disallowed by explaining that Barefoot sought a constitutional rule barring an entire category of expert testimony. ${ }^{73}$ The Court was "not persuaded that such testimony is almost entirely unreliable" and so opined that the adversary system would be competent to take account of its shortcomings. ${ }^{74}$

Although the Court found "no constitutional barrier to applying the ordinary rules of evidence governing the use of expert testimony," rules of evidence have changed, and these changes have illuminated the extreme unreliability and irrelevance of expert testimony that has no empirical foundation masquerading as science. Barefoot was wrongly decided, both as a matter of evidentiary due process and because it was empirically wrong about the ability of the adversary system to sort out the reliable from the unreliable expert testimony. ${ }^{76}$ Barefoot is egregiously wrong-headed by current standards for reliability, ${ }^{77}$ and its effect on capital sentencing proceedings has been pernicious and pervasive, undermining fundamental fairness in a way wholly contrary to the rule of law. ${ }^{78}$ Perhaps it is true, as Justices Blackmun and Powell contended, that the death penalty cannot be administered in a way that meets con-

72. Barefoot, 463 U.S. at 898 ("[T]he rules of evidence generally extant at the federal and state levels anticipate that relevant, unprivileged evidence should be admitted and its weight left to the fact finder, who would have the benefit of cross-examination and contrary evidence by the opposing party."). Post-Daubert, the Federal Rules of Evidence require judges to act as gatekeepers to ensure that only scientifically valid expert testimony be admitted.

73. Id. at 899 .

74. Id. at 901 (holding that because the adversary process could be "trusted to sort out the reliable from the unreliable evidence and opinion about future dangerousness," the expert testimony should not be excluded on that basis).

75. Id. at 904.

76. See Beecher-Monas \& Garcia-Rill, supra note 6; Daniel A. Krauss \& Bruce D. Sales, The Effects of Clinical and Scientific Expert Testimony on Juror Decision Making in Capital Sentencing, 7 PSYCHOL. PUB. POL'Y \& L. 267, 273-77 (2001) (discussing research that suggests jurors are incapable of differentiating more scientifically valid expert testimony from less accurate testimony).

77. Although the argument has been made that Daubert is not technically inconsistent with Barefoot because Daubert involved interpretation of the Federal Rules of Evidence, while Barefoot involved interpretation of the Due Process clause of the Constitution, nearly everyone acknowledges the tension between the two decisions. See, e.g., Craig J. Albert, Challenging Deterrence: New Insights on Capital Punishment Derived from Panel Data, 60 U. PITT. L. REV. 321, 338 (1999) ("[I]t goes too far to say simply that Daubert impliedly overruled Barefoot, [but] . . . they cannot co-exist as a matter of common sense."). Moreover, no one persuasively argues that the testimony at issue in Barefoot could meet Daubert standards. See also 1 DAVID L. FAIGMAN ET AL., MODERn SCIENTIFIC EVIDENCE: THE LAW AND SCIENCE OF EXPERT TESTIMONY 298-99 (1997) (acknowledging that the testimony proffered in Barefoot could not meet Daubert standards); Paul C. Gianelli, Daubert: Interpreting the Federal Rules of Evidence, 15 CARDOZO L. REV. 1999 (1994) ("Daubert required a higher standard for money damages than Barefoot required for the death penalty.").

78. See Beecher-Monas \& Garcia-Rill, supra note 6. 
stitutional requirements. ${ }^{79}$ If so, it appears that sexual offender statutes are similarly impervious to rule of law precepts.

\section{Hendricks and Crane}

In Kansas v. Hendricks ${ }^{80}$ the Supreme Court examined the constitutionality of the Kansas Sexually Violent Predator Act (Kansas Act) ${ }^{81}$ which provides for the indefinite civil commitment of people who are likely to engage in future "predatory acts of sexual violence" due to a "mental abnormality or personality disorder." ${ }^{\prime 2}$ Because it requires a finding of likely future violence, the Kansas Act appears to provide for an expert's prediction of future dangerousness.

The defendant, Leroy Hendricks, had been "convicted of taking 'indecent liberties' with two thirteen-year[-]old boys." ${ }^{, 3}$ He served a ten-year sentence for his crime. Shortly before he was due to be released to a halfway house, the state sought civil commitment under the Kansas Act. ${ }^{84}$ During his commitment trial before a jury, Hendricks testified that he had five prior convictions for sexually molesting children and had been treated at and discharged from a state psychiatric institution, after which he continued to abuse children, including his own stepchildren. ${ }^{85}$ He testified that when he was under stress he could not "control the urge," and that the only way he could keep from sexually molesting children in the future was "to die."

Both the state's expert and the defendant's expert testified about future dangerousness. The state's experts were a clinical social worker and a psychologist, both of whom opined that Hendricks was a pedophile. ${ }^{87}$ The psychologist testified that, unless confined, Hendricks was likely to commit sexual offenses in the future. ${ }^{88}$ Hendricks' expert, a psychiatrist, testified that 'it was not possible to predict with any degree of accuracy the future dangerousness of a sex offender." ${ }^{\prime 9}$ The jury was nonetheless persuaded beyond a reasonable doubt by the state's evidence that Hendricks was likely to commit a future

79. See Callins v. Collins, 510 U.S. 1141, 1145-46 (1994) (Blackmun, J., dissenting) ("[T]he inevitability of factual, legal, and moral error gives us a system that we know must wrongly kill some defendants, a system that fails to deliver the fair, consistent, and reliable sentences of death required by the Constitution."); Jeffrey L. Kirchmeier, Aggravating and Mitigating Factors: The Paradox of Today's Arbitrary and Mandatory Capital Punishment Scheme, 6 WM. \& MARY BILL RTS. J. 345, 347 (1998) ("Justice Powell came to a similar conclusion after his retirement."). Notably, two states, Illinois and Maryland, have reached similar conclusions, and have placed a moratorium on death penalty prosecutions because of due process concerns. See Dirk Johnson, Illinois, Citing Verdict Errors, Bars Executions, N.Y. TIMES, Feb. 1, 2000, at A1.

80. 521 U.S. 346 (1997).

81. KAN. StAT. ANN. §§ 59-29a01-29a21 (1994).

82. Id. §§ 59-29a01-29a07.

83. Hendricks, 521 U.S. at 353.

84. Id. at 354 .

85. Id.

86. Id. at 355 .

87. Id. at 355 n.2.

88. Id.

89. Id. 
crime, the judge determined that pedophilia qualifies as a mental abnormality under the statute, and Hendricks was committed.

The issues on appeal included due process, double jeopardy, and ex-post facto clause claims. The Kansas Supreme Court accepted Hendricks's due process claim, holding that substantive due process requires a showing, by clear and convincing evidence, that the person to be committed is both mentally ill and poses a danger to himself or to others. ${ }^{90}$ The United States Supreme Court disagreed, holding that the Kansas Act's definition of mental abnormality satisfied due process requirements. Although the Court acknowledged that involuntary commitment statutes must adhere to "proper procedures and evidentiary standards," it did not discuss those standards. ${ }^{91}$ It did not mention Barefoot, Daubert, the need for reliability, or any scientific basis for the expert testimony on dangerousness. It cited a 1984 case for the proposition that "there is nothing inherently unattainable about a prediction of future criminal conduct,", ${ }^{, 2}$ but it did not elaborate. And although it acknowledged the need for a showing of "more than a mere predisposition to violence," it determined that the Kansas Act's twin requirements of evidence of past sexual offenses and present mental abnormality making recidivism likely were sufficient. ${ }^{93}$ Nowhere did the court grapple with the scientific basis for a prediction of future dangerousness.

In Kansas v. Crane ${ }^{94}$ the Supreme Court revisited the Kansas Act to determine the application of Hendricks to the indefinite civil commitment of a convicted flasher. ${ }^{95}$ Michael Crane had been convicted and had served time for lewd and lascivious behavior, after which the state sought civil commitment under the Kansas Act. Crane argued the state had not proved that he completely lacked control over his behavior and that Hendricks required such a showing.

The Supreme Court held that although the state need not prove a complete lack of control under the Kansas Act, the Constitution does require some "proof of serious difficulty in controlling behavior," manded the case for such a determination. ${ }^{97}$ Once more, however, the Court

90. Id. at 356 .

91. Id. at 357.

92. Id. at 358 (citing Schall v. Martin, 467 U.S. 253, 278 (1984)).

93. Id. The Court acknowledged that dangerousness alone was not enough for indefinite involuntary commitment but held that a showing that the offender continues to have inadequate control over his behavior due to a present mental abnormality would suffice. Id. at 358, 364 .

94. 534 U.S. 407 (2002).

95. Crane was convicted of lewd and lascivious behavior for exposing himself to a tanning salon attendant. In re Crane, 7 P.3d 285, 286 (Kan. 2000). The prior conduct required for commitment under the Kansas Act consisted of an aggravated sexual battery conviction that was overturned on appeal. Id. The event giving rise to the sexual battery charges actually occurred thirty minutes after Crane left the tanning salon. Id. He entered a video store, grabbed a clerk, exposed himself, and threatened to rape her before suddenly stopping and running out of the store. Id. Crane pled guilty to aggravated sexual battery, which met the requirement for prior sexual offense history. Id.

96. Crane, 534 U.S. at 411.

97. Id. at $413,415$. 
avoided any discussion of whether predictions of dangerousness were reliable or what such predictions could mean in the context of an exhibitionist.

Future dangerousness testimony based on clinical judgment alone has been overwhelmingly castigated by the profession and so fails peer review, publication, and the general acceptance prongs of Daubert. ${ }^{98}$ Clinical predictions of future dangerousness are not based on scientific study, nor do they even purport to be based on the scientific method. Because such predictions are frequently wrong, they cannot meet the error rate inquiry. ${ }^{99}$ Even actuarial predictions, though somewhat more accurate than clinical predictions, still are tenuous. ${ }^{100}$ Nonetheless, even though they cannot meet criteria for valid science, expert predictions are widely used as a basis for deprivations of life and liberty. ${ }^{101}$ The admission of such testimony appears to be a result of the extraordinary public pressure on courts and legislatures to control crime.

\section{III}

\section{DATA ON ViOLENCE AND SEXUAL VIOLENCE}

Public pressure for strengthened crime control measures is fueled by stories of sexual murders - especially those of children - as well as of gang homicides and rape, which occupy the national and international media and feed the fears of an increasingly violent society. ${ }^{102}$ Certainly, the U.S. prison population is growing at an alarming rate. ${ }^{103}$ Violence in America is world famous, is per-

98. Id.

99. Although the experts in Barefoot made bald assertions that they were invariably accurate, they offered no substantiation for their claims. Barefoot v. Estelle, 463 U.S. 880, 896-97 (1983).

100. Beecher-Monas \& Garcia-Rill, supra note 6, at 1845 n.3.

101. See Scherr, supra note 3, at 2 ("[W]e should expect the rules of evidence ... to require the exclusion of predictive expertise ... no appellate court has ever ordered exclusion."). Professor Scherr contends that this is because it is expedient for the courts to rely on expert opinions, and that they therefore meet the "fit" requirements of Daubert. Id. at 2-3. While courts overwhelmingly admit expert future dangerousness testimony (and probably do so because they find it expedient), they rarely articulate any principled basis for doing so. We disagree with Professor Scherr that unscientific predictions can meet Daubert requirements, either for reliability or fit. Rather, we argue that the courts should not circumvent their gatekeeping duties in this way.

102. There is some question about whether this perception that violence is increasing in society is accurate. Some commentators have asserted that violence is actually decreasing over time as society industrializes, and remark that violence in tribal societies is still prevalent. MARTIN DALY \& MARGO WiLsON, HOMICIDE 291 (Sarah Blaffer Hardy \& Richard W. Wrangham eds., Aldine De Gruyter 1988) (1944). For example, homicide is estimated to have accounted for $35 \%$ of the adult male mortality and $29 \%$ of the adult female mortality among tribal peoples in New Guinea and the Amazon. Id. Daly and Wilson further note that "[e]ven the gentle Kung San foragers of the Kalahari desert had a homicide rate approximately equivalent to that of the most violent urban American ghettos." Id. Moreover, most crimes labeled "violent" are really batteries involving no physical injuries; when physical injuries are present, they usually do not require medical treatment, and even if they do, they do not require hospitalization. BUREAU OF JUST. STAT., U.S. DEPT. OF JUSTICE, CRIMINAL VICTIMIZATION IN THE UNITED STATES 18-19, 22-23, 75-76, 95 (2000), available at http://www.ojp.usdoj.gov/bjs/pub/pdf/cvus00.pdf.

103. See Joseph E. Kennedy, Monstrous Offenders and the Search for Solidarity Through Modern Punishment, 51 HAstings L.J. 829, 831 (2000) ("The number of people in prison in the United States 
ceived to be increasing over time, and is considered a threat to civil society. ${ }^{104}$ Violent recidivism is likewise perceived to be a horrifying reality, although the base rate of violent recidivism is actually quite low. ${ }^{105}$ In response, there has been an increased emphasis on preventive detention and death, magnifying the role of future dangerousness predictions. Predictions about behavior, however, are empirically problematic.

\section{A. Actuarial Predictions}

Concerned about the inaccuracy of clinical predictions, researchers began to study ways to improve the accuracy of future dangerousness predictions. ${ }^{106}$ Their goal was to develop an empirically based actuarial instrument that would reflect a state-of-the-art understanding of the factors correlated with violence and their interrelationships. ${ }^{107}$ These risk factors would then be combined to create a scoring instrument that took into account the interrelationship of various risk factors and the population base rates, then assigned weight to the individual risk factors. The instrument would then yield an overall "score" that ranked levels of risk. ${ }^{108}$

Currently, it is well accepted that actuarial instruments offer the most accurate way of making future dangerousness predictions. ${ }^{109}$ The predominant in-

has increased by almost $500 \%$ since 1972 while the population itself has increased by only $28 \%$."). In 1997 the prison population had grown to 1.2 million from 200,000 in 1972. Id. at 831 n.6. When probation and parole are included, $3 \%$ of the population was under some form of correctional supervision in 1998. Id. at 832-33 (citing the high number of Americans under correctional supervision and espousing a Durkheimian view that excessive punishment is the attempt of a fragmenting society to bind itself together).

104. See Franklin E. Zimring, Will Success Spoil James Q. Wilson?, 85 J. CRIM. L. \& CRIMINOLOGY 828, 830 (1995) (reviewing CRIME (James Q. Wilson \& Joan Petersilia eds., 1995) ("U.S. rates of property crime other than robbery are near the rates of other Western nations, while U.S. lethal violence rates are four to eight times the rates of other highly developed nations.").

105. See R. Karl Hanson et al., Sex Offender Recidivism: What We Know and What We Need to Know, in SEXUALly COERCIVE BeHAVIOR, supra note 5, at 154, 163 ("Overall, the observed rates [of sexual recidivism] are between $10 \%$ and $15 \%$ after 5 years and approximately $20 \%$ after 10 years."). The base rate of sexual recidivism rates for rapists was reported at $18.9 \%$, and $12.7 \%$ for child molesters. R. Karl Hanson \& Monique T. Bussière, Predicting Relapse: A Meta-Analysis of Sexual Offender Recidivism Studies, 66 J. CONSUlting \& ClinICAL PSYCHOL. 348, 351 (1998).

106. Christopher Webster ET AL., The Violence Prediction Scheme: Assessing DANGEROUSNESS IN HigH RISK MEN xi, xii (1994) (describing the genesis and goals of the violence risk assessment guide).

107. See id.; see also VERNON L. QUINSEY ET AL., VIOLENT OFFENDERS: APPRAISING AND MANAGING RISK 190 (1998).

108. See Monahan, supra note 5, at 905-10 (evaluating risk assessment instruments). The concept of risk encompasses not only the presence of danger, but its probability of occurrence. See Eric S. Janus \& Robert A. Prentky, Forensic Use of Actuarial Risk Assessment with Sex Offenders: Accuracy, Admissibility and Accountability, 40 AM. CRIM L. REV. 1443, 1448-49 (2003) (addressing the concept of risk in predictions).

109. A number of studies of these instruments have shown that actuarial measures are more accurate predictors than clinical judgment. See, e.g., Mark D. Cunningham \& Thomas J. Reidy, Don't Confuse Me With the Facts: Common Errors in Violence Risk Assessment at Capital Sentencing, 26 CRIM. JUST. \& BEHAV. 20, 28 (1999) (stating that repeated studies of actuarial methods have demonstrated them to be superior to clinical judgment standing alone); Mairead Dolan \& Michael Doyle, Violence 
strument used in assessing violence (including sexual violence) is the Violence Risk Assessment Guide (VRAG). ${ }^{110}$ The predominant instruments for sexual offender risk assessment are the Sexual Offender Risk Assessment Guide $(\mathrm{SORAG})^{111}$ and the Rapid Risk Assessment for Sexual Offense Recidivism (RRASOR). ${ }^{112}$ Of these, the VRAG is "the best currently available method to predict future violence." ${ }^{113}$ Its close cousin, the SORAG, is not quite as accurate. ${ }^{114}$

In each of these instruments, violent behavior (violent sexual behavior in the SORAG and RRASOR) is statistically correlated ${ }^{115}$ with specific factors in the person's past behavior (a pattern of past violence, for example), circumstances (such as poverty), attitudes toward others (failure to marry or form equivalent relationship), medical and psychiatric history (age when problems began and any injuries to the brain), and substance abuse (alcohol or drugs). ${ }^{116}$ The sexual violence instruments tend to include phallometric studies. ${ }^{117}$ They also include factors such as whether the victim was a stranger and whether the

Risk Prediction: Clinical and Actuarial Measures and the Role of the Psychopathy Checklist, 177 BRIT. J. PSYCHOL. 303, 305-09 (2000) (citing results of studies on clinical risk assessment tools and their predictive validity); Robert A. Prentky, A 15-Year Retrospective on Sexual Coercion: Advances and Projections, in SEXUALly COERCIVE BEHAVIOR, supra note 5, at 13, 21 ("[T]he predictive efficacy of actuarial methods of risk assessment are superior to clinically derived assessments of risk."). One reason for this may be that "much of the information commonly assessed in these [clinical] interviews, such as low victim empathy, denial, and lack of motivation for treatment, were unrelated to sexual offense recidivism." Hanson et al., supra note 105, at 158.

110. QUINSEY ET AL., supra note 107, at 141.

111. Id. at $155-59$ (proposing SORAG as an enhancement to VRAG).

112. RRASOR is based on four factors: prior sexual offenses, age at release (young is worse), gender of the victim (male is worse), and relationship to the victim (related is better). Mee \& Hall, supra note 7, at 102. In their discussion, Mee and Hall included the Minnesota Sex Offender Screening TestRevised (MnSOST-R) as a sex offender instrument. Id. at 107. However, Barbaree's study found that it "failed to meet conventional levels of statistical significance in the prediction of serious and sexual recidivism" and so it has been omitted here. See Howard E. Barbaree et al., Evaluating the Predictive Accuracy of Six Risk Assessment Instruments for Adult Sex Offenders, 28 CRIM. JUST. \& BEHAV. 490, $512(2001)$.

113. Mee \& Hall, supra note 7, at 102.

114. Id. at 102 n.227 (citing interview with the developer of both the VRAG and the SORAG).

115. As Stephen Gould explains, "Correlation assesses the tendency of one measure to vary in concert with another." GOULD, supra note 1, at 269. Correlation, with regard to linear relationships, is measured by using Pearson's product moment correlation coefficient, which ranges from +1 for perfect positive correlation, 0 for no correlation, to -1 for perfect negative correlation. Id. at 270.

116. See Hanson \& Bussière, supra note 105, at 353-56 (discussing and comparing risk factors). These factors are not "causes" of violence. They are factors that are associated with violence. See Stephan F. Lanes, Error and Uncertainty in Causal Inference, in CAUSAL INFERENCE 173, 182-85 (Kenneth J. Rothman ed., 1988) ("The uncertainty in causal inference is attributable to the fact that we cannot establish that an association is valid."). An unidentifiable error may exist and it may cause the observation. Id. The most that can be expected of strength of association and the level of statistical significance is that they affect subjective beliefs. See id. at 186 .

117. "Phallometry is a diagnostic method to assess sexual arousal by measuring blood flow (tumescence) to the penis during the presentation of potentially erotic stimuli in the laboratory." CTR. FOR Sex OfFender Mgmt., Understanding Juvenile SeXual OfFending Behavior: EMERging RESEARCH, TREATMENT APPROACHES, AND MANAGEMENT PRACTICES (1999), $\mathrm{http} / /$ www.csom.org/pubs/juvbrf10.html. The report also notes that this is a controversial practice and explains the pitfalls involved, especially with juvenile offenders. $I d$. 
victim was male. ${ }^{118}$ These factors are then used in combination to assess a level of probability of future risk. The variables considered for the instruments are drawn from empirical studies showing a statistical association with violent (or sexually violent) behavior. ${ }^{119}$

Even such instruments and their structured reasoning requirements, however, do not obviate all the problems of human judgment. ${ }^{120}$ Structured analysis offers many advantages in light of the difficulty people have in synthesizing differently weighted likelihoods of varying significance such as risk factors for violent behavior; ${ }^{121}$ but the actuarial instrument is only as effective as the risk factors used and the weight given them, making accurate prediction elusive in all but the highest of the risk categories. ${ }^{122}$ For example, the risk factor descriptions may be vague, decreasing their reliability, ${ }^{123}$ and sometimes the factors are not independent, as with anger and the inability to sustain relationships. ${ }^{124}$

118. See Hanson et al., supra note 105, at 157 (discussing risk factors as predictors of sexual offense recidivism).

119. "Association" means that there is a statistically significant correlation of a particular factor with violent behavior. Statistical significance is set by convention at a level of significance, or p-value of 0.05 , which corresponds to a confidence level of $95 \%$. The object of statistical significance tests is to keep the scientist from asserting a positive effect when the effect may actually be due to chance. See David Ozonhoff \& Leslie I. Boden, Truth \& Consequences: Health Agency Responses to Environmental Health Problems, 12 SCI. TECH. \& HuM. VAlues 70, 73-74 (1987) (stating that statistical significance testing tries to avoid accepting results as significant when they may have been arrived at only by chance). If the p-value is 0.01 , the evidence is said to be highly statistically significant. Stephen E. Fienberg et al., Understanding and Evaluating Statistical Evidence in Litigation, 36 JURIMETRICS J. 1, 22 (1995). Fienberg further clarifies, "By rejecting a hypothesis only when the test is statistically significant, we have placed an upper bound, $5 \%$ on the chance of rejecting a true hypothesis." Id. Another way of explaining this is that it describes the probability that the procedure produced the observed effect by chance. See id. If the test is not statistically significant, it may either be because the results were due to chance or because the test lacked the power to discern a difference between the null hypothesis and the proposed effect. See id. Power increases with the size of the study and with the degree of difference from the null hypothesis (the more extreme the alternatives, the better the power). See id.

120. It is important to bear in mind that risk is a social construct. Although it uses probabilistic analysis and quantification, it is not an exact science. See THE ROYAL SOCIETY, RISK: ANALYSIS, PERCEPTION AND MANAGEMENT 7 (1992) (explaining that some subjectivity is always a part of risk assessment). Indeed, all science is value-laden, and risk assessment is not different in that regard. See generally Erica Beecher-Monas, The Heuristics of Intellectual Due Process: A Primer for Triers of Science, 75 N.Y.U. L. REV. 1563 (2000) (acknowledging the subjectivity inherent in all scientific methodologies and proposing a five-step framework to follow for sound analysis of scientific evidence).

121. J. Richard EISER \& JOOP VAN DER Pligt, ATtiTudes AND DECISIONS 100 (1988) ("[A]ccuracy declines considerably when the number of features or the number of alternatives increases [and the]... reliability with which choice rules are used tends to decrease as the decisionmaker's information load increases.").

122. See Morse, supra note 31, at 59 ("It is a truism of behavioral science that statistical, 'cookbook' prediction based on empirically validated risk factors is more accurate than clinical prediction, but despite advances in the database that have improved the cookbook, highly accurate prediction by any method eludes us in all but the most obvious cases.").

123. See David Carson, A Risk-Management Approach to Legal Decision-Making About 'Dangerous' People, in LAW AND UNCERTAINTY: RISKS AND LEGAL PROCESSES 255, 258 (Robert Baldwin ed., 1997) (noting the problem of reliability). For example, even trained clinicians may differ on what exactly is meant by "glibness" (a factor on the PCL-R) or "lack of insight" (a factor on the VRAG and HCR-20).

124. Id. 
Moreover, all future dangerousness predictions rely heavily on prior criminal record as an important factor, which is both under- and over-inclusive. It is under-inclusive because it misses violence between intimates, which accounts for the highest percentage of violent acts. Many people with violently aggressive behaviors and a high likelihood of repeating violent behavior, such as chronic spouse abusers and stalkers, do not have criminal records. Using one's criminal record as an important factor is also over-inclusive, because it does not allow for the decrease in aggression that occurs with aging or other dynamic factors. ${ }^{125}$

Although testimony based on actuarial instruments is more accurate than clinical predictions ${ }^{126}$ and thus preferable to clinical testimony, these predictions are still tenuous bases for making important decisions such as sentencing a defendant to death or to indefinite confinement. At best, these actuarial instruments correlate only moderately with violence and violent sexual recidivism. ${ }^{127}$ Thus, if the instruments are to meet standards for scientific validity, the expert must carefully explain the limits of such testimony. ${ }^{128}$ In order to be helpful, the

125. For example, three-strikes rules premised on the notion that repeated bad behavior escalates in violence overlook the natural decrease in aggression after adolescence. See Farrington, supra note 32, at 425 ("[T]he highest prevalence of homicide is between the ages seventeen and twenty-two."). Thus, while offending rates drop after the twenties, three-strikes rules are often triggered "just when the natural forces of aging would rein in the offenders." Robinson, supra note 33, at 1451. Moreover, with treatment, most adolescent brains can be retrained. The abnormal stress responses in violent offenders can be normalized with medication, such as the "selective and thoughtful use of medications that normalize stress responses, delay impulsive reactions, block the craving for drugs, or suppress nonlethal paraphilias." NIEHOFF, supra note 10, at 265. Further, the time period that the risk assessment is to cover, the circumstances under which it will be implemented (confinement or release), and the individual's motivation to refrain from violence (including motivation to comply with treatment), are all dynamic factors that should be taken into consideration in assessing risk, but are not. See, e.g., Janus \& Prentky, supra note 108, at 1479 (acknowledging that the absence of dynamic factors "may seriously undermine the assessment power of [actuarial risk assessment] tools" but contending nonetheless that they are superior to clinical judgment).

126. There is some evidence that a multidisciplinary team may be able to rival the accuracy of actuarial instruments. See Julian Fuller \& Justin Cowan, Risk Assessment in a Multidisciplinary Forensic Setting: Clinical Judgement Revisited, 10 J. FORENSIC PSYCHIATRY 276, 286 (1999) (acknowledging that a multidisciplinary team may provide increased accuracy, approaching that of actuarial instruments). However, such teams are unlikely to be employed in capital sentencing or sexual predator determinations. See, e.g., Beecher-Monas, supra note 13, at 362 (describing clinical future dangerousness testimony at capital sentencing hearings).

127. See Barbaree et al., supra note 112, at 492-93 (noting VRAG correlations of 0.44 with violent recidivism and RRASOR correlations of 0.27 with sexual recidivism); Janus \& Prentky, supra note 108 , at 1471 (noting the efficacy of VRAG, SORAG, and RRASOR and explaining that the "correlation between the SORAG and violent recidivism was 0.38 "). As Janus and Prentky observed, "all ... [actuarial] instruments have shortcomings, and these shortcomings detract from the reliability of the instruments." Id. Another measure of accuracy is a statistical analysis known as the Relative Operating Characteristic (ROC). Mark Binderman, Understanding VRAG: The Violence Risk Assessment Guide, 10(1-2) FORENSIC EXAMINER 28, 29 (2001). A test that is no better than chance would have an ROC of 0.50 ; the VRAG's ROC was 0.76 , which means that "if an offender were drawn randomly from each of the recidivist and nonrecidivist groups, there was a probability of 0.76 that the recidivist had the higher score on the VRAG." QUINSEY ET AL., supra note 107, at 148. This is a statistically significant result, comparable to ROC scores for predictions in meteorology and medical imaging. Binderman, supra, at 29.

128. Cf. John Monahan \& Henry J. Steadman, Violent Storms and Violent People: How Meteorology Can Inform Risk Communication in Mental Health Law, 51 AM. PSYCHOLOGIST, 931, 935-36 (1996) 
expert needs to educate the jury in a scientifically sound manner, which includes explicitly stating the statistical basis for the opinion. ${ }^{129}$ Violence risk assessment is not a yes or no dichotomy; instead, actuarial assessments are probabilistic risk estimates that should be acknowledged as uncertain. ${ }^{130}$ At most, these instruments offer a partial answer, and courts should demand more. ${ }^{131}$

\section{B. The Biology of Violence and Sexual Violence}

What is missing from any of the actuarial instruments is causal theory, recognition of the biology of violence, and explicit discussion of the interrelatedness of genes, organisms, and their environment. Thus, the instruments do little to advance our understanding about violent behavior and give us no insight into prevention other than removal from society. However, there has been an explosion of knowledge about how biological factors, including genetic factors, combined with environmental factors such as stress and substance abuse $\mathrm{e}^{132}$ can increase the chances that a particular individual will become violent. Indeed, many of the risk factors measured by actuarial assessments may be tied to an underlying biological function. But no testable theoretical basis is advanced for why the risk factors correlate with violence. Thus, a major problem with each of the risk instruments is its failure to correlate the risk factors with the biology of violence and to articulate a hypothesis for the mechanisms of violence. ${ }^{133} \mathrm{Un}$ -

(explaining that predictions of the risk of future violence should be modeled explicitly on weather predictions, with all their qualifiers and uncertainties).

129. See Cunningham \& Reidy supra note 109, at 34-35 (advocating that experts limit their testimony to predominantly statistical analyses, in order to avoid going beyond the limits of their scientific expertise).

130. Beecher-Monas \& Garcia-Rill, supra note 6, at 1868. It is important that juries be informed that even the most accurate of the actuarial instruments made predictions of dangerousness for people that did not, in fact, later commit acts of violence. Id. at 1898-99. For example, of people who were placed in the "high risk" category under the VRAG, only 55\% actually committed violent acts upon release. Id. at 1878 . That means $45 \%$ did not. Had the "high risk" prediction been the basis for a death sentence, nearly half the people sentenced to death would not, in fact, go on to commit any more acts of violence.

131. Cf. David L. Faigman, The Law's Scientific Revolution: Reflections and Ruminations on the Law's Use of Experts in Year Seven of the Revolution, 57 WASH. \& LEE L. REV. 661, 667, 678 (2000) ("A lot of previously admitted evidence, especially evidence offered by prosecutors, appears excludable for want of a research base.... Psychologists should hesitate before seeking to bring their findings to policymakers, fearful that when tested the research might be thought not-yet-done.").

132. Alcohol consumption, which can effectively shut down the activity of small brain cells responsible for cortical function, figures into two out of every three violent crimes. Judith Roizen, Issues of Epidemiology of Alcohol and Violence, in ALCOHOL AND INTERPERSONAL VIOLENCE: FOSTERING MulTidisCIPLINARY PERSPECTIVES 20 (Susan E. Martin ed. 1993). We use the cerebral cortex to assess and plan responses, rather than "knee-jerking." If the cortex loses some of its inhibitory power, such as by deactivation of cortical circuits under the influence of alcohol, some of that regulation is lost and "primordial," instinctive behaviors are released. The frontal lobes of the brain, of which the cerebral cortex is a part, are our most highly evolved brain structures. They are in charge of critical judgment and learning. Frank N. Dempster, The Rise and Fall of the Inhibitory Mechanism: Toward a Unified Theory of Cognitive Development and Aging, 12 DEV. REV. 45, 48-51 (1992).

133. See Harris et al., supra note 12, at 197 (attempting to correlate the Psychotherapy ChecklistRevised (PCL-R) with neuroscience and conceding that much research still needs to be done). 
til there is an understanding of how violence occurs, there will be little ability to control or predict it.

\section{The Evolutionary Perspective}

Current research on the biology of violence suggests that violence is "normal" aggression gone awry. ${ }^{134}$ In this view, aggression is thought to be part of the normal repertoire of behaviors that has arisen to balance the individual's need to look out for himself and still to maintain good standing within the group. ${ }^{135}$ That violent behavior is part of our normal repertoire of responses to certain situations does not mean that it is desirable. ${ }^{136}$ It does mean that in order to understand and control violence, we need to probe the situations that elicit violent responses and the complex biological mediators of these responses. ${ }^{137}$

From the perspective of evolutionary biology, the situations eliciting aggression and violence commonly involve competition for reproductive resources..$^{138}$ In humans, demographically speaking, most violence is perpetrated by young males against other unrelated young males under circumstances in which risktaking improves their chances of reproductive success. ${ }^{139}$ Even spousal murders and infanticide can be viewed as aggressive responses to threats to reproductive success. ${ }^{140}$ Most spousal homicides result from male attempts to exert control

134. Richard J. Davidson et al., Dysfunction in the Neural Circuitry of Emotion Regulation: A Possible Prelude to Violence, 289 SCIENCE 591, 591 (2000).

135. NIEHOFF, supra note 10, at 76.

136. DALY \& WILSON, supra note 102, at 57 (noting that although violence may be abhorrent, it cannot be pathological, because pathology connotes a breakdown in biological systems and "people and other animals possess complex psychophysiological machinery that is clearly designed for the production and regulation of violence").

137. See id. at 60-61 (giving the example of bird mate-guarding paternity assurance as a testable hypothesis arising from "explanations of why particular proximal objectives and motivators have evolved to play their particular roles in the causal control of behavior, and why they are calibrated as they are."). The mate-guarding behavior of birds, for example, varies in relation to observable clues about female fertility, as well as the proximity, abundance, and attractiveness of male rivals. $I d$.

138. See id. at 294-95 (noting young men with dismal prospects are the most likely to be victims and perpetrators of homicide, competing for control over the reproductive capacities of women); JARED DiAmOND, COllaPSE: How SOCIETIES CHOOSE TO FAIL OR SUCCEED 319-28 (2005) (arguing that societal collapse, including the Rwandan genocide, is frequently the result of a confluence of factors resulting in Malthusian population pressures exploding into violence when large numbers of young men cannot command the assets to attract women and begin their own families). For example, in mice bred for aggression the aggression trait did not begin to manifest until the animals reached sexual maturity, and then began to wane with age and repeated interactions with less aggressive mice. See Robert B. Cairns, Aggression from a Developmental Perspective: Genes, Environments and Interactions, in Genetics OF CRIMINAL AND ANTISOCIAL BeHAVIOUR 45, 47-48 (Gregory R. Bock \& Jamie A. Goode eds., 1996) (hypothesizing aggressive behavior, including violent behavior, may be flexible responses to social conditions that reflect dynamic interactions realigning the nervous system with the outside social world).

139. See DALY \& Wilson, supra note 102, at 294 (noting that the predominant form of homicide is between "unrelated men, especially young men whose dismal prospects make dangerous escalation of social competition attractive").

140. For example, in gorillas, a victorious challenging male will kill all the suckling offspring in the vanquished male's harem, thus causing the female to stop lactating and go into estrus. See MATT Ridley, The AgIle GenE: How NATURE TuRns ON NuRTuRe 19-20 (2004) ("Infanticide is common among gorillas, as it is among many primates."). 
over women's reproductive capacities and women's efforts at independence from coercion. ${ }^{141}$ Whether rape is a reproductive strategy is more contentious, with some scholars claiming it to be a "natural," genetically based reproductive strategy, ${ }^{142}$ and others claiming that rape is not a reproductive, but an aggressive and dominance strategy - a weapon, not an appetite. ${ }^{143}$ No one has yet advanced an evolutionary strategy as the basis for pedophilia.

\section{Behavioral Traits}

Of course, individuals vary in their responses to given situations, and this must be due at least in part to genetic variations among individuals. ${ }^{14}$ Differences in personality account for a large percentage of behavioral differences. ${ }^{145}$ But while behavioral diversity within populations undoubtedly has some genetic aspects, behavioral differences may also be due in part to differences in the environment in which each individual matured and resides. All behavior is a complex intermingling of nature and nurture. ${ }^{146}$

a. Stress responses. Stress responses also demonstrate this complex interaction. Although most violence is perpetrated by young men against other young men, violent tendencies can develop prenatally ${ }^{147}$ or in early infancy ${ }^{148}$ or

141. See Margo Wilson et al., Lethal and Nonlethal Violence Against Wives, 17 CAN. J. CRIMINOLOGY 331, 343-44 (1995) (observing escalation of violence toward wives as a correlate of other controlling behaviors); DALY \& WILSON, supra note 102, at 295 ("[M] ale sexual proprietariness is the principal source of conflict in the great majority of spousal homicides.").

142. RAndy Thornhill \& CRAig T. PAlmer, A NATural History of Rape: Biological BASES OF SEXUAL COERCION 59 (2000) (claiming that rape may be an adaptation favored by natural selection because it increases male reproductive success by increasing a male's mating partners). But see Elizabeth A. Lloyd, Violence Against Science, in EVOLUTION, GENDER AND RAPE 235, 235-57 (Cheryl B. Travis ed., 2003) (discrediting Thornhill and Palmer's "reduced view of rape as sex" and identifying weaknesses in their evolutionary theory of why men rape).

143. See NIEHOFF, supra note 10, at 164 (claiming rape is motivated by aggression and noting testosterone blocking drugs chill sexual behavior but not anti-social aggression); Grant T. Harris et al., Appraisal and Management of Risk in Sexual Aggressors: Implications for Criminal Justice Policy, 4 PSYCHOL. PUB. POL'Y \& L. 73, 85 (1998) (“[A]lthough rapists are more dangerous [than child molesters] (i.e., more likely to exhibit violent recidivism) overall, much of that violence does not appear to be sexually motivated.").

144. See V. Elving Anderson, Genes, Behavior, and Responsibility: Research Perspectives, in THE GENETIC FrontiER: ETHICS, LAW AND Policy 105, 105-06 (Mark S. Frankel \& Albert H. Teich eds., 1994) (explaining that although few behaviors are completely without genetic and environmental influences, "genes do not determine one's destiny in a predictable manner" and the effects are not unidirectional: genes can influence behavior, but behavior can also affect genetic expression).

145. Cf. Tooby \& Cosmides, supra note 14, at 18 (noting the challenge individual variation poses to theories of evolutionary psychology).

146. See NIEHOFF, supra note 10, at 51-53 (discussing the complex inter-relationship of biology and the environment).

147. See, e.g., Constance Holden, The Violence of the Lambs, 289 SCIENCE 580, 580 (2000) ("Researchers are increasingly coming to view violence as the end result of multiple risk factors that may include a biological vulnerability-either genetic or created in the prenatal environment-that can be brought out or reinforced in the social environment.").

148. Frans B. M. De Waal, Primates: A Natural Heritage of Conflict Resolution, 289 SCIENCE 586, 588 (2000) (discussing the violence between two infant monkeys after displaying aggression and biting each other). 
can emerge after the onset of puberty. ${ }^{149}$ Environmental factors often play a role. ${ }^{150}$ Disruption of animals' early environment can cause increased nervous system sensitivity to stress. ${ }^{151}$ Variations in maternal care also influence the development of hormonal stress response. ${ }^{152}$ All mammals, including humans, socialize their young. It may be that "neuropsychological impairments disrupt normal development and increase vulnerability" to poor social environments. ${ }^{153}$

Curiously, although crowding has often been considered a factor in aggressive behavior, this does not appear to be the case in primates. ${ }^{154}$ Even in rodents, social isolation can produce aggression that intensifies as the isolation time increases, particularly when such isolation takes place at puberty. ${ }^{155}$ Physiological responses to environmental stimuli can also predispose individuals to engage in violent behavior. For example, although some violent criminals have lowered central nervous system $(\mathrm{CNS})^{156}$ and autonomic nervous system (ANS) arousal, ${ }^{157}$ others have heightened arousal. ${ }^{158}$ Depression, violent aggres-

149. See, e.g., NIEHOFF, supra note 10 , at 159.

150. See, e.g., Darlene Francis et al., Nongenomic Transmission Across Generations of Maternal Behavior and Stress Responses in the Rat, 286 SCIENCE 1155, 1158 (1999) ("[I]ndividual differences in the expression of genes in brain regions that regulate stress reactivity can be transmitted from one generation to the next through behavior... [through] differences in maternal care during the first week of life.").

151. NIEHOFF, supra note 10, at 274.

152. Francis et al., supra note 150 , at 1155 .

153. James C. Howell \& J. David Hawkins, Prevention of Youth Violence, 24 CRIME \& JUST. 263, 268 (1998) (citing Terrie E. Moffitt, Adolescence-Limited and Life-Course-Persistent Antisocial Behavior: A Developmental Taxonomy, 100 PsYCHOL. REV. 674 (1993)); cf. Morse, supra note 31, at 56 ("[A]ll societies that survive surely place limits on risk and will act to prevent danger from those for whom socialization has apparently failed.").

154. See Frans B. M. De WaAl, Tree of Origin: What Primate Behavior Can Tell Us ABOUt HUMAN SOCIAL EVOLUTION 41, 48 (2001) ("[T] he connection between crowding and aggression, initially demonstrated in rodents, fails to hold in monkeys and apes.").

155. D. Brunner \& R. Hen, Insights into the Neurobiology of Impulsive Behavior from Serotonin Receptor Knockout Mice, 836 ANNALS N.Y. ACAD. SCI. 81 (1997); see also NIEHOFF, supra note 10, at 269 (discussing studies finding that aggression in isolated rats becomes expressed most strongly after puberty).

156. The normal human CNS displays immediate, short-term, instinctive reflexive activity as a first line of defense to real or perceived threats.

157. Measures of antisocial behavior in fifteen-year-old males have been correlated with reduced autonomic nervous system activation. See Adrian Raine et al., Autonomic Nervous System Factors Underlying Disinhibited, Antisocial, and Violent Behavior: Biosocial Perspectives and Treatment Implications, 794 ANNALS N.Y. ACAD. SCI. 46, 48 (1996) (reviewing nine-year prospective study of crime development and noting it is the "first study providing evidence for underarousal in an antisocial population in all three psychophysiological response systems"). Further studies showed that measures of underarousal of the CNS and ANS taken at fifteen years of age were related to criminality status assessed at twenty-four years of age. Adrian Raine et al., Relationships Between Central and Autonomic Measures of Arousal at Age 15 Years and Criminality at Age 24 Years, 47 ARCHIVES GEN. PSYCHIATRY 1003, 1003 (1990).

158. NIEHOFF, supra note 10, at 181. Lowered levels of arousal were accompanied by decreased activation of the reticular activating system (RAS), which is the part of the brain that controls sleep/wake cycles and arousal, and lowered hypothalamic-modulated stress responses. See id. Generally speaking, the hypothalamus, along with the RAS, helps regulate the body's physiological response to stress, often referred to as "fight or flight." ROBERT M. SAPOLSKY, STRESS, THE AGING BRAIN, AND THE MECHANISMS OF NEURON DEATH 3-9 (1999). For a more detailed discussion of the stress response, see Edgar Garcia-Rill \& Erica Beecher-Monas, Gatekeeping Stress: The Science and Admissi- 
sion, and antisocial personality disorder have all been linked to problems with the stress response. ${ }^{159}$ Although each of these disorders has a different pattern of expression, all are associated with abnormal endocrine feedback, norepinephrine and serotonin functions, and altered glucocorticoid levels. ${ }^{160}$ Studies of recidivistic violent offenders, adults with antisocial personality disorder, and antisocial adolescents have all documented statistically significant reductions in levels of cortisol, the main circulating stress hormone. ${ }^{161}$ This suggests that inappropriately violent behavior may sometimes involve a stress response disorder, one in which the response to a threat is too weak rather than too strong. People who appear to lack a conscience may actually lack the biological machinery necessary to warn them that they are heading for disaster. ${ }^{162}$

Early environmental cues may calibrate behavior irrevocably. ${ }^{163}$ Moreover, these early cues may indicate the kind of social environment the child has been born into. For example, a person who has been treated violently in childhood has likely "been born into a social environment where violence is an important avenue of social instrumentality." ${ }^{164}$ Thus, exposing a child to violence may permanently lower the threshold for activation of the "fight or flight" response and may account for the disproportionate aggression in adults who were abused as children. ${ }^{165}$ Undoubtedly, some of these effects may have a genetic component. But genes do not determine behavior. They may increase the probability a behavior will occur, but they do not cause it directly. ${ }^{166}$

b. Sex hormones. Hormones, which are regulated by the hypothalamus and the ANS, can play a role as well. Testosterone affects levels of aggression even in the womb, at least in mice, whose intrauterine positioning between sib-

bility of Post-Traumatic Stress Disorder, 24 U. ARK. LiTTLE ROCK L. REV. 9, 12-14 (2001). In order to initiate "fight or flight" responses, there must be an initial arm, an arousal response, and the part to the brain that fulfills that function is the RAS. The RAS projects into many regions, simultaneously alerting the cortex to the event and priming the motor system to be able to fight or flee. It also projects to the hypothalamus, where the arousal response triggers the stress response.

159. NIEHOFF, supra note 10 , at 183.

160. Id.

161. Id. at 181. For additional information on the studies cited by Niehoff, see also Bo Bergman \& Bo Brismar, Hormone Levels and Personality Traits in Abusive and Suicidal Male Alcoholics, 18 Alcoholism: ClinicAl \& ExPERIMENTAL ReS. 311, 311-15 (1994); Keith McBurnett et al., Anxiety, Inhibition, and Conduct Disorder in Children: II. Relation to Salivary Cortisol, 30 J. AM. ACAD. CHILD \& AdOLESCENT PSYCHIATRY 192 (1991); Matti Virkkunen et al., CSF Biochemistries, Glucose Metabolism, and Diurnal Activity Rhythms in Alcoholic, Violent Offenders, Fire Setters, and Healthy Volunteers, 51 ARCHIVES GEN. PSYCHIATRY 20 (1994); Matti Virkkunen, Urinary Free Cortisol Secretion in Habitually Violent Offenders, 72 ACTA PSYCHIATRICA SCANDANAVICA 40, 40 (1985).

162. See NIEHOFF, supra note 10 , at 181 ("[N]o warning bell of anxiety or disgust sounds when ... [antisocial individuals are] about to commit an atrocity.").

163. Tooby \& Cosmides, supra note 14 , at 54.

164. Id.

165. Id.

166. Robert Plomin \& Michael Rutter, Child Development, Molecular Genetics, and What to Do with Genes Once They Are Found, 69 CHILD DEVELOPMENT 1223, 1224 (1998). 
ling males and females affects levels in post-birth aggression. ${ }^{167}$ Testosterone in boys surges at age ten, rising to a plateau by age fourteen, when aggressive behavior starts accelerating. ${ }^{168}$ Males start to kill each other at an appreciable rate only after they reach adolescence. ${ }^{169}$ This is also the age at which hormone levels are fluctuating widely. However, delinquent behavior, adjustment problems, and rebelliousness are actually more likely to be associated with lower testosterone levels. ${ }^{170}$ Apparently, testosterone functions as a sensitizer, permitting males to match the social environment with an appropriate response. ${ }^{171}$

\section{Impaired Brains}

Structural dysfunction may also contribute to violent behavior. Damage, the decreased metabolizing and uptake of glucose, reduced blood flow to the frontal lobes, and reduced function have all been observed in the frontal cortex of violent individuals and murderers. ${ }^{172}$ Studies using positron emission tomography (PET) and single photon emission computed tomography (SPECT), which are imaging devices designed to measure brain function by showing changes in the metabolism of glucose, have demonstrated that murderers have decreased glucose utilization in the frontal lobes compared to age- and gendermatched subjects. ${ }^{173}$

How do we perceive the world around us? We process information first through evolutionarily conserved, instinctive systems. ${ }^{174}$ That is, we inherited a spinal cord and brainstem very similar to those in lower species. These parts of the brain have virtually identical functions in lower species and include basic processes like sleep-wake cycle control, respiration, and locomotion, along with

167. Frederick S. vom Saal, Models of Early Hormonal Effects on Intrasex Aggression in Mice, in Hormones AND AgGressive BeHAVIOR 197, 198 (Bruce B. Svare ed., 1983).

168. NIEHOFF, supra note 10 , at 159.

169. See DALY \& WILSON, supra note 102, at 22 ("[Fourteen] is about the age at which people begin to kill one another at an appreciable rate.").

170. NIEHOFF, supra note 10 , at 160 .

171. Renee J. Primus \& Carol K. Kellogg, Gonadal Hormones During Puberty Organize Environment-Related Social Interaction in the Male Rat, 24 HORMONES \& BEHAV. 311, 320 (1990) ("The presence of testosterone [in rats]... appears to be critical for the expression of environment-related changes [in social interaction].").

172. Adrian Raine et al., Brain Abnormalities in Murderers Indicated by Positron Emission Tomography, 42 BIOLOGICAL PSYCHIATRY 495, 495-504 (1997); Adrian Raine et al., Selective Reductions in Prefrontal Glucose Metabolism in Murderers, 36 BIOLOGICAL PsYCHIATRY 365, 365-73 (1994). The subjects in these studies did not differ in handedness, schizophrenia, ethnicity, etc. Id. at 365.

173. Adrian Raine et al., Reduced Prefrontal and Increased Subcortical Brain Functioning Assessed Using Positron Emission Tomography in Predatory and Affective Murderers, 16 BEHAV. SCI. \& L. 319, 319-30 (1998). This study was extended to a population of impulsive murderers compared to a group of predatory violent offenders, and the results suggest that impulsive murderers have decreased glucose metabolism in the frontal lobes while predatory murderers do not. Id. at 319; see also Nora D. Volkow \& Laurence Tancredi, Neural Substrates of Violent Behaviour: A Preliminary Study with Positron Emission Tomography, 151 BRIT. J. PSYCHOL. 668, 668-72 (1987) (showing a pattern of decreased activity in the frontal cortex of a group of murderers as compared to controls and hypothesizing that temporocortical dysfunction may implicate emotional reasoning).

174. ANTONiO R. DAMASIO, DESCARTES' ERROR: EMOTION, REASON, AND THE HUMAN BRAIN 111 (1994). 
primordial drives such as those related to feeding, drinking, procreation, and emotions. These systems were conserved in evolution because of their survival value, their success in "fight or flight" responses.

On the other hand, more advanced species evolved a series of newer brain structures, in particular, the cerebral cortex. ${ }^{175}$ Humans have much greater amounts of cerebral cortex than other primates and apes, which allows us to reach vastly greater heights, in evolutionary terms. On an everyday basis, these newly evolved parts of the brain receive their information from the older, primordial, emotional systems. However, they do this in the context of a complex environment and, importantly, within the process of enculturation.

In general, the role of the cortex is to control, through inhibition, those old parts of the brain. ${ }^{176}$ If the cortex loses some of its inhibitory power, therefore, "primordial" behaviors are released. This can occur when, for example, the cortex suffers from decreased blood flow, or metabolism, known as "hypofrontality." Instinctive behaviors can then be released, including exaggerated "fight or flight" responses to misperceived threats-that is, violent or exaggerated behavior in an attempt to attack or flee. Hypofrontality is evident in such disorders as schizophrenia, post-traumatic stress disorder, and depression. ${ }^{177}$ Damage, decreased uptake of glucose, reduced blood flow, and reduced function have all been observed in the frontal cortex of violent individuals and murderers. ${ }^{178}$

175. Dempster, supra note 132.

176. Joaquín M. Fuster, Frontal Lobe and Cognitive Development, 31 J. NeUROCYTOLOGY 373, 373-85 (2002).

177. See, e.g., Edgar Garcia-Rill, Disorders of the Reticular Activating System, 49 MED. HYPOTHESES 379, 379-82 (1997) (reviewing study that showed hypofrontality in schizophrenic patients). Hypofrontality may also lead to the release of "fixed action patterns" which are more complex than instincts. Fixed action patterns are automatic brain modules that make complex movements. Rodolfo R. LlinÁs, I OF THE VoteX: From NEURONS TO SELF 133 (2001). These patterns can result in repetition of sequences of movements, for example, stabbing repeatedly, and may be part of uncontrolled action patterns rather than rage. Hypofrontality has been shown to occur during dreaming, Pierre Maquet et al., Functional Neuroanatomy of Human Rapid-Eye-Movement Sleep and Dreaming, 383 NATURE 163, 163 (1996). This may explain why we accept our dreams so readily, why we do not question that we are flying or embroiled in an unrealistic situation. Overreactions to innocuous stimuli are likely in these disorders, particularly the anxiety disorders. Events or conditions could easily lead to exaggerated responses such as panic attacks or incapacitation like fear of leaving the house. Cornering such individuals or placing them under undue stress could elicit exaggerated reactions, such as striking out due to overperceived threats.

178. Raine et al., Brain Abnormalities, supra note 172. See also Hugo D. Critchley et al., Prefrontal and Medial Temporal Correlates of Repetitive Violence to Self and Others, 47 BIOLOGICAL PSYCHIATRY 928, 931 (2000); J. Graffman et al., Frontal Lobe Injuries, Violence, and Aggression: A Report of the Vietnam Head Injury Study, 46 AM. ACAD. NeUrology 1231, 1231 (1996). 
Additional studies have found abnormal temporal lobe metabolism ${ }^{179}$ and lesions of the frontal lobes associated with an increased risk of aggressive and violent behavior. ${ }^{180}$ Reduced volumes of frontal and temporal cortex have been observed in violent and antisocial personality disorder patients. ${ }^{181}$ Interestingly, adolescents on average show a mild form of this condition. The brain, especially the frontal lobes, is still maturing during adolescence, so that the fullblown inhibition exercised by this region in adulthood is not yet in play. ${ }^{182}$ Magnetic resonance imaging (MRI) testing in adolescents shows mild decreases in frontal lobe function compared to that in adults, which, coupled with increased levels of sex hormones, can lead to hyper-responsiveness to stimuli. ${ }^{183}$ These results suggest that reduction of function in the frontal lobes may be responsible for impaired critical judgment and poor impulse control. ${ }^{184}$

On the other hand, lack of empathy, rather than impaired impulse control, may result from damage to the amygdala. ${ }^{185}$ Studies on amygdalar function suggest that damage to this part of the brain might lead to disengagement and lack of empathy. ${ }^{186}$ While electrically stimulating the amygdala can elicit the physiological and behavioral signs of emotional states, ${ }^{187}$ lesions to the amygdala induce an unusually placid and emotionally unengaged individual, a condition

179. See David Seidenwurm et al., Abnormal Temporal Lobe Metabolism in Violent Subjects: Correlation of Imaging and Neuropsychiatric Findings, 18 AM. J. NEURORADIOLOGY 625, 625 (1997) (discussing study finding abnormalities in the glucose metabolism in the temporal lobe correlated with violent behavior in humans); Henrik Soderstrom et al., Reduced Regional Cerebral Blood Flow in NonPsychotic Violent Offenders, 98 PsYCHIATRY RES. NEUROIMAGING 29, 40 (2000). The temporal lobe contains limbic structures like the hippocampus and amygdala, which are associated with emotional states.

180. Graffman et al., supra note 178.

181. Critchley et al., supra note 178; Adrian Raine et al., Reduced Prefrontal Gray Matter Volume and Reduced Autonomic Activity in Antisocial Personality Disorder, 57 ARCHIVES GEN. PSYCHIATRY 119, 119 (2000).

182. Jay N. Giedd et al., Brain Development During Childhood and Adolescence: A Longitudinal MRI Study, 2 NATURE Neurosci. 861, 861-62 (1999); Elizabeth R. Sowell et al., In Vivo Evidence for Post-Adolescent Brain Maturation in Frontal and Striatal Regions, 2 NATURE NeUROSCI. 859, 859-61 (1999).

183. Younger individuals (eight to twenty years of age) show less efficient activation of the frontal lobes than older adults. Leanne Tamm et al., Maturation of Brain Function Associated With Response Inhibition, 41 J. AM. ACAD. CHILD \& AdOLESCENT PSYCHIATRY 1231, 1231-38 (2002). Normal adolescents also appear to have a sensory gating deficit, whereby they over-respond to repetitive or inconsequential stimuli. Lisa Rasco et al., Effect of Age on Sensory Gating of the Sleep State-Dependent P1/P50 Midlatency Auditory Evoked Potential, 3 SLEEP RES. OnLINE 97, 97-105 (2000), available at http://www.sro.org/bin/article.dll?Paper\&1930\&0\&0. This can lead to increased distractibility, which can also create unnecessary responsiveness to inconsequential stimuli. Id. Given a stressful environment or other condition that increases arousal, such as hormones, the chances of exaggerated responsiveness-too much "fight" or too much "flight"-are increased.

184. R. J. R. Blair, Neurocognitive Models of Aggression, The Antisocial Personality Disorder, and Psychopathy, 71 J. NeUROLOGY, NEUROSURGERY \& PSYCHIATRY 727, 728 (2001).

185. The amygdala is an almond shaped structure deep inside the front end of the temporal lobe and part of the limbic system, the "emotional" part of the brain. NIEHOFF, supra note 10, at 94.

186. Id. at 96-97 (stating that the removal of the amygdala can turn an animal into an emotionally unavailable being).

187. Id. at 92 . 
known as the Kluver-Bucy syndrome. ${ }^{188}$ Those affected are unable to recognize or respond emotionally to a situation that elicits emotional responses in others, although they are capable of emitting the right gestures for those emotions. Such lack of empathy may be at the root of multiple, premeditated, and serial, as opposed to impulsive, killing. ${ }^{189}$

\section{Sexual Violence}

Far less is known about sexual paraphilias ${ }^{190}$-offenses other than rape that sexually violent predator statutes address, which typically involve child molestation. Surprisingly little biological research has been done on sex offenders. ${ }^{191}$ Demographically, nearly half the sex offenses against children are perpetrated by other children, usually the victim's family members, ${ }^{192}$ and ninety percent of the rapes of children younger than twelve are committed by someone the victim knows. ${ }^{193}$ However, most sexual predator statutes apply only when the victim was a stranger. The primary impetus for passing these statutes was the sexual murder of children by strangers, yet statistics show that these crimes represent fewer than one percent of all murders. ${ }^{194}$

In contrast to other murders, most child victims of sexual murders are female, although a greater risk of recidivism occurs when the victim is male. ${ }^{195}$

188. DAMASIO, supra note 174, at 134-39.

189. See Beecher-Monas \& Garcia-Rill, supra note 6, at 1866.

190. See Martin P. Kafka, The Monoamine Hypothesis for Pathophysiology of Paraphilic Disorders: An Update, in SEXUAlly COERCIVE BEHAVIOR, supra note 5, at 86-87 ("[P]araphilias found predominantly in males, are repetitive, compelling, socially deviant behaviors that are associated with personal distress, harm to others, or other expressions of significant psychosocial impairment."). This definition excludes adult rapists. Id. at 87.

191. See, e.g., Grant T. Harris \& Marnie E. Rice, Actuarial Assessment of Risk Among Sex Offenders, in SEXUALLY COERCIVE BEHAVIOR, supra note 5, at 199 (noting that the actuarial instruments for sexual recidivism were "based on a surprisingly small amount of empirical work").

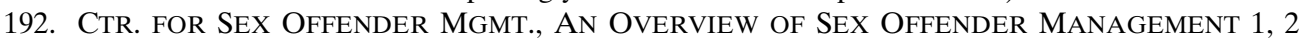
(2002), available at http://www.csom.org/pubs/csom_bro.pdf. For several reasons this population should be excluded, including its being overwhelmingly characterized by psychiatric disorders (80\%) and learning disabilities (30-60\%). CTR. FOR SEX OFFENDER MGMT., MYTHS AND FACTS ABOUT SEX OFFENDERS (2000), http://www.csom.org/pubs/mythsfacts.html. Moreover, there is no evidence to show that sexually abusive youth become sex offenders as adults. AN OVERVIEW OF SEX OFFENDER MANAGEMENT, supra, at 2. Unfortunately, this has not stopped the increasing treatment of juveniles as adults in the criminal justice system, where juvenile court waivers have become increasingly common, the age at which juveniles may be tried as adults has been lowered, and minimum age restrictions for trying juveniles as adults in certain serious crimes have been abandoned. See id. at 4-6 (noting the increasing level of accountability in the criminal justice system).

193. LAwrence A. Greenfield, Bureau of Just. Stat., U.S. DePT. OF Justice, An AnAlysis of DAta on RAPE AND SEXuAl AsSAult: SEX OfFEnSES AND OFFENDERs i, iii (1997), available at http://www.ojp.usdoj.gov/bjs/pub/pdf/soo.pdf.

194. Id. at *vi; see also Roxanne Lieb et al., Sexual Predators and Social Policy, 23 CRIME \& JUST. $43,52-53$ (1998) (noting that about $1.5 \%$ of murders involve rape or sexual assault).

195. Lawrence A. Greenfield, Bureau of Just. Stat., U.S. DePt. of Justice, Child VICTIMIZERS: VIOLENT OFFENDERS AND THEIR VICTIMS iv (1996), available at http://www.ojp.usdoj.gov/bjs/pub/pdf/cvvoatv.pdf (reporting "3 in 4 child victims of violence were female."). 
The base rate of sexual re-offending appears to be low, well below that of general or even violent recidivism. ${ }^{196}$

Very little is known about pedophilia in adult males. Pedophiles seem to be an older crowd: nearly twenty-five percent of child victimizers are forty or older ${ }^{197}$ although most recidivists are younger. ${ }^{198}$ Approximately thirty percent of all adult sex offenders were sexually abused as children. ${ }^{199}$ Although being exposed to physical violence in childhood predisposes adults to violence, it is unclear whether being exposed to sexual abuse in childhood has the same effect on sexual offending by adults. ${ }^{200}$

Some potentially important physiological anomalies have been observed in pedophiles. Right temporal lobe hypometabolism has been identified in adult pedophiles ${ }^{201}$ as have lower baseline cortisol levels ${ }^{202}$ and monoaminergic dysfunction. ${ }^{203}$ Although pedophilia is not well studied, some researchers believe that neurological deficits, chromosome aberration, or early childhood abuse or sexual experience may imprint desire onto inappropriate outlets. ${ }^{204}$ The best available evidence suggests some disruption in the development of the neurosystem. ${ }^{205}$

196. The exact numbers appear to be somewhat in dispute. The Bureau of Justice Statistics reports that sexual offender recidivism is set at about five percent, and child molesters' recidivism appears at about three percent. BUREAU OF JUST. STAT., U.S. DEPT. OF JUSTICE, CRIMINAL OFFENDER STATISTICS (2005), available at http://www.ojp.usdoj.gov/bjs/crimoff.htm (last visited Nov. 13, 2005). However, the Center for Sex Offender Management reports that recidivism is set at a thirteen percent reconviction rate for child molesters and nineteen percent for rapists. MYTHS AND FACTS ABOUT SEX OFFENDERS, supra note 192. In either event, the "recidivism rates for sex offenders are lower than for the general criminal population." Id.; cf. Hanson et al., supra note 105, at 353 (finding that although recidivism rates for rapists and child molesters are about equal for sexual offenses, rapists are more likely to commit another violent act).

197. See CRIMINAL OFFENDER STATISTICS, supra note 196.

198. Hanson et al., supra note 105, at 353.

199. MYTHS AND FACTS ABOUT SEX OFFENDERS, supra note 192.

200. See, e.g., John Monahan et Al., Rethinking Risk Assessment: The MacArthur STUDY OF MENTAL DisORDER AND VIOLENCE 54-55 (2001) ("Although [a child's] prior physical abuse... [is] associated with post-discharge violence, prior sexual abuse was not."); CTR. FOR SEX OfFEnder Mgmt., Understanding Juvenile SEXUAl OfFending BeHAVIOR: EMERging Research, TREATMENT APPROACHES AND MANAgEMENT PRACTICES (1999), available at $\mathrm{http} / / /$ www.csom.org/pubs/juvbrf10.html (reporting that twenty to fifty percent of sexually abusive youth had a history of physical abuse, while forty to eighty percent had a history of sexual abuse).

201. Mario F. Mendez et al., Pedophilia and Temporal Lobe Disturbances, $12 \mathrm{~J}$. NEUROPSYCHIATRY \& CLINICAL NEUROSCI. 71, 71-76 (2000) ("A predisposition to pedophilia may be unmasked by hypersexuality from brain disease.").

202. See Michael Maes et al., Lower Baseline Plasma Cortisol and Prolactin together with Increased Body Temperature and Higher mCPP-Induced Cortisol Responses in Men with Pedophilia, 24 NEUROPSYCHOPHARMACOLOGY 37, 37-44 (2001) (studying hormonal and serotonergic alterations in pedophiles).

203. See Kafka, supra note 190, at 91 ("[A] specific role for these neuromodulators in the paraphilic condition remains neither proven nor rejected.").

204. See F. S. Berlin \& E. Kraut, Pedophilia Diagnostic Concepts, Treatment and Ethical Considerations, 7 AM. J. ForensiC PsYCHOL. 13 (1986); F. S. Berlin et al., A 5-Year Follow-Up Survey of Criminal Recidivism, 12 AM. J. FORENSIC PSYCHOL. 5 (1991).

205. Berlin et al., supra note 204, at 208 ("[T]he best available evidence suggests that most sexual deviance and paraphilia is caused by very early biomedical events leading to neurodevelopmental disruption."). 
Violent behavior therefore appears to be both universal and individualboth normal aggression gone awry and pathological breakdowns in biological systems, both nature and nurture. Multiple hormones and neurotransmitters, and a multitude of genes, contribute to aggression, along with the social environment, context, and timing. Personality and genetics are undoubtedly involved, as are social circumstances like status, future prospects, and relative wealth. Violence is complex behavior. Why would identifying the genetic contributions not aid the accuracy of future dangerousness predictions?

IV

\section{BEHAVIORAL GENETICS AND FUTURE DANGEROUSNESS}

\section{A. Assumptions about Human Nature}

The explosion of scientific information related to the determination of the human genome has created an unfortunate misunderstanding by manyincluding scientists - of the role that genes play in behavior ${ }^{206}$ The assumptions go something like this: Genes made us the way we are; therefore, we are driven by a set of rigid, genetically determined predilections towards some behaviors. The force of this genetic dictatorship makes us less responsible for our actions, mainly because genetic "determinism" is absolute and irreversible. Such views are used to influence increasingly restrictive laws presumably aimed at curbing the worst in us. How did we arrive at such a state? Is this really true?

A prime example of how such views came to be integrated into our assumptions, our "belief system," is The Selfish Gene, by Richard Dawkins, which became influential soon after being first published in 1976. ${ }^{207}$ Dawkins theorizes that "we, and all other animals, are machines created by our genes." 208 This prompts Dawkins to argue that a predominant quality in a "successful gene," defined as one is passed on from generation to generation, is ruthless selfishness and that it will usually give rise to selfishness in individual behavior. Dawkins essentially used the theory of natural selection proposed by Darwin as one potential mechanism behind evolution and applied it to gene selection. Presumably, genetic selection was simply too dry a subject on its own; it needed some pizzazz, and voilà, the dog-eat-dog process of natural selection was the ideal concept to muster interest. The gene became "selfish" because it tends to perpetuate itself; it became "ruthless" because it was in "competition" with its alleles. Dawkins used this series of unsupported conclusions to argue further that, since genes can influence behavior (unsupported conclusion), we tend to-

206. See, e.g., Anderson, supra note 144, at 105 ("Genes do not directly cause behavior, since their effect is expressed indirectly through physiological systems."). Even if genetic correlations to violence are identified, "many individuals with abnormal genotypes will be completely normal." Id. at 126.

207. RiCHARD DAWkins, THE SELFISH GENE (Oxford Univ. Press 1989) (1976).

208. Id. at 2. 
ward selfish behavior (unsupported conclusion). As usual, two wrongs do not make a right.

Such unfortunate categorical language has led to great misunderstanding. Many readers, and some who never read the book at all, stopped at the inflammatory, basic theory that the "gene is the basic unit of selfishness"209 (unsupported conclusion) and applied the concept to complex behaviors. To the author's credit (and in response to the uproar ${ }^{210}$ ), Dawkins tempered this extreme notion by arguing that, rather than being strictly deterministic, genes "determine" our behavior only in a statistical sense ${ }^{211}$ (adding another unsupported conclusion). The author, considering-seemingly ineffectively-how easily this misunderstanding has been perpetuated, argued further that the effect of the gene depends on the environment, including other genes: "Sometimes a gene has one effect in the presence of a particular other gene, and a completely different effect in the presence of another set companion genes." 212 Although this position provides a glimpse into the precarious conditions mandating genetic expression, it still gives genes far too much power-power they do not have. There is no evidence to suggest that genes dictate behavior "in a statistical sense," or otherwise.

\section{B. Nature vs. Nurture, Again}

One basic question regarding the development of the nervous system is how much influence genetic programming (nature) has compared to environmental factors (nurture). ${ }^{213}$ Only a few years ago, many believed it was the environment that made us who and what we are. ${ }^{214}$ Our parents were responsible for our neuroses; failed relationships and divorce were considered learned behaviors. Even the environment we lived in was blamed for our depression.

Now the reigning mode of explaining development, individual differences, and even behavior is genetics. ${ }^{215}$ Nowadays, some believe-falsely-that there is a gene for this behavior and a gene for that behavior-that some genes make us violent, some make us depressed, and others make us gregarious. Hopefully, though, it will become evident that the development of the brain relies on neither nature nor nurture, but on both. In fact, the effect of environmentnurture-is what makes individuals of a species different. That is, the differences between rats, tigers, chimps, and humans can be explained by differences in their genetic makeup, but to explain the differences between two individual

209. Id. at 36 .

210. E.g., Merlin W. Donald, A Mind So Rare: The Evolution of Human Consciousness 4 (2001) (observing that deterministic theories of mind, such as those espoused by Dawkins, make "great inferential leaps from genes to culture and ignor[e] a good deal of what we know about the brain").

211. Id. at $37-40$.

212. Id. at 37.

213. See generally DAVID S. MOORE, THE DEPENDENT GENE 72 (2001).

214. Richard Lewontin, The Triple HeliX: Gene, ORGAnism, AND EnVIRONMENT 16 (1998).

215. Id. 
chimps or two individual humans, more is needed than their genetic differences. $^{216}$

First, to put genes in perspective: Inside the nucleus of a cell is deoxyribonucleic acid, or DNA, which is like two strings of pearls twisted around each other in a double helix. Each string has four different types of pearls; the particular sequence of a number of pearls is a gene-a code used for the manufacture of a protein, ${ }^{217}$ So DNA contains many, many genes, each of which codes for one or more proteins. When activated, genes-pieces of DNA-make different kinds of proteins. ${ }^{218}$ Just as the DNA is like the blueprint for a building, the proteins are the building materials-brick, mortar, metal, and wood-that create a cell.

But DNA is not two-dimensional like a blueprint; it is a linear chain of coding, a specific sequence of pearls. And the organism whose information is encoded is three-dimensional. Therefore, the cell actually created may resemble its blueprint only in principle. A particular gene does not always code for a particular protein: although many genes appear to produce only one primary protein, other genes produce alternative forms of these proteins. ${ }^{219}$ These proteins may start or end at different sites along the coded region and may have more than one site for alternative splicing of proteins. A single stretch of DNA may thus encode a variety of proteins. Sometimes a cell may express these different proteins; in other cases, the pattern is subject to developmental regulation. That is, one gene can encode many different proteins, often with divergent functions. $^{220}$ Environmental factors-environmental "noise" - may also play a role in cellular structure, just as a complex set of environmental circumstances, including the builder's experience, the workers' dedication, the terrain, the weather, the economy will affect the building's integrity, despite its blueprint.

The environment can alter, in turn, genetic expression. For example, when water fleas, those little bugs that skip along the surface of water, are raised in a lab aquarium containing the scent of fish-their main predator-they will express a "helmet" that makes them harder to swallow. When no scent of fish is present, water fleas with identical DNA will not express a helmet. ${ }^{221}$ Thus, the environment can elicit markedly different traits from the same DNA and a given genotype can develop in different ways, depending on the environment.

Similarly, maternal care can change the expression of a gene in rats that makes them fearful and jumpy. Rat pups regularly licked and groomed by their

216. Id. at 17. Indeed, some believe that the organism is determined neither by its genes nor its environment, or the interactions between them, but that "developmental noise" introduces a random process that leads to great variation in individual differences. $I d$. at 38.

217. See generally MOORE, supra note 213, at 67-81.

218. J.Z. YOUNG, AN INTRODUCTION TO THE STUdY OF MAN 60 (1971).

219. BAsic NeUrochemistry: Molecular, Cellular AND MEDiCAl Aspects 421 (George J. Siegel et al. eds., Lippincott-Raven Pubs. 6th ed. 1999).

220. Id.

221. Lehman et al., A Hierarchical Molecular Phylogeny within the Genus Daphnia, 4 MOLECULAR PHYLOGENETICS \& EVOLUTION 395, 395 (1995). 
mothers instead grow up to be calm and curious. ${ }^{222}$ Closer to home, geneticists investigated the claim that a gene called 5-HTT is associated with depression and suicide. ${ }^{223}$ When people experience very stressful events, they found, those who carry this gene are more likely to suffer from depression than those with the "healthy" variant. ${ }^{224}$ The genes themselves are not connected to depression or aggression in the absence of exposure to environmental risk. Again, differing environments can produce different traits from the same or a different genotype. It may be that genes allow us a plasticity in responding to the environment, rather than hard-wiring our behavior. What is innate, our human nature, is actually our flexibility to respond to a complex environment.

\section{Genes Make Proteins, Not Behavior}

Behavior is generated by and dependent upon a complex nervous system. Genes alone do not make behavior, they make proteins. A collection of proteins make a nerve cell, but it takes more than nerve cells alone to generate behavior. Brain cells, once constructed, must be connected accurately into working circuits or systems, such as motor or visual systems. Within each of these systems, every cell seeks its specific synaptic targets, other nerve cells with which they will synapse and communicate to create the working system. If that search is thwarted, the cell may never find a target and will die. This is the process of programmed cell death, ${ }^{225}$

A pervasive and well-supported theory of brain development, programmed cell death describes the development of some systems in the brain as follows: The developing brain system makes about twice as many cells as it will end up with in the adult. ${ }^{226}$ Every distinct group of cells within that system must link up with its appropriate synaptic target (or targets) in order to create a circuit (or circuits) within that system. The target for a specific group of cells expresses a specific growth factor, like a perfume that attracts only certain suitors, and the cells begins sending out axons-arm-like appendages-that pursue the chemical gradient of growth factor secreted by a target, growing towards it. Those axons that reach the target first will feast on the growth factor, consolidating their synaptic link and keeping the cell of origin alive. The axons of cells that arrived too late will find no site at which to synapse and be nurtured, and they will consequently die.

Programmed cell death—survival of the fastest—is very much like developmental natural selection. The process of establishing appropriate connections in many brain regions is essentially stochastic, and, as such, it is extremely vul-

222. E.W. Fish et al., Epigenetic Programming of Stress Responses through Variations in Maternal Care, 1036 ANNALS N.Y. ACAD. SCI. 167, 167 (2004).

223. Avshalom Caspi et al., Influence of Life Stress on Depression: Moderation by a Polymorphism in the 5-HTT Gene, 301 SCI. 386, 386 (2003).

224. $I d$.

225. Robert R. Buss \& Ronald W. Oppenheim, Role of Programmed Cell Death in Normal Neuronal Development and Function, 79 ANATOMICAL SCI. INT’L. 191, 191 (2004).

226. See generally MOORE, supra note 213, at 82-103. 
nerable to environmental conditions. For example, if the environment of the fetus is disturbed during the time when the main links are being made-namely, during the first and second trimesters-abnormal connectivity may result. If the neurochemical environment is changed dramatically, too few cortical cells may survive, as in oxygen compromise leading to mental retardation; or too many cells may survive, as in over-expression of growth factors, which may be the case in some schizophrenics. ${ }^{227}$ Between these extremes is the potential for a great number of milder effects on cell survival, none genetically determined, that may give rise to individual differences. Even if all goes well and one group of cells connects appropriately with another, all the process creates is a very basic nervous system, one still incapable of "behavior."

Lots of different cells and several different systems interconnected in sufficiently complex ways will lead to behavior, but to only simple behavior, as long as there is no environmental influence. For example, imagine that we could grow a complex nervous system in the absence of an environment, or in a neutral environment. ${ }^{228}$ Such a nervous system, no matter how complex, would carry out only simple behaviors. It might eat, breathe, walk-basically it could survive and carry out presumably innate functions. But without an appropriate environment, the nervous system will not be shaped appropriately and will not function normally. It will not learn, remember, plan, or behave in socially acceptable (or unacceptable) ways. An example of the pervasive effects of environment is the classic sensory deprivation study of Melzack, in which puppies were brought up in the dark, without social interaction, amidst white noise and wearing collars to prevent grooming or contact with extremities. ${ }^{229}$ These dogs grew up to sniff an open flame without realizing their noses would burn and without reacting in pain. When the study was repeated, however, the results could not be replicated. One night, returning to the lab, Melzack found the reason. A cleaning person had felt sorry for the dogs and had released them from their collars and cages in the evening. Such brief exposure to the environment was nevertheless enough to normalize complex behaviors.

Not until all the brain systems are in place, coupled with exposure to an appropriate environment, do we start "behaving" normally or abnormally. Early in development, we learn to move, plan, and interact with others. The combination of a good genetic program and the exposure to a proper environment creates a well-functioning nervous system.

But even then, these behaviors are not written in stone. We modify our brain connections throughout our lifetimes, usually in response to our surround-

227. Edgar Garcia-Rill et al., Mesopontine Neurons in Schizophrenia, 66 NEUROSCIENCE 321, 321 (1995).

228. This is strictly an intellectual exercise as there can be no organism without an environment, just as there can be no environment without an organism. LEWONTIN, supra note 214, at 48 .

229. Ronald Melzack \& T. H. Scott, The Effects of Early Experience on the Response to Pain, $50 \mathrm{~J}$. COMP. PHYSIOL. PSYCHOL. 155, 155-60 (1957). Melzack's procedures are unlikely to meet approval from regulatory committees today. 
ings. Some of these modifications are carried out by proteins, proteins that are coded by genes. For example, consolidation of memories is believed to be caused by the triggering of genes to manufacture proteins that fortify a set of synapses so that when the circuit is activated, the memory may be recalled. ${ }^{230}$ This means genes remain an active part of our everyday functions, of our behavior. But what triggers the genetic expression is nerve activity as a result of interaction with the environment. That is, such genes are at the beck and call of our now fully functioning nervous system; they are not dictating what the nervous system does, but they are tools our nerve cells use to mold the everchanging brain.

Moreover, we are capable of changing our behavior as long as we live. What each of us ultimately becomes is influenced by multiple environmental factors at many points during our lifetime, from conception (microenvironment) to birth and adulthood (macroenvironment).

The sequence of events is that genes make proteins, which make cells, which make connections, which make systems, which make brains that are responsible for behavior. In other words, the brain needs genes to create networks before it can realize its potential to control behavior. At every point in this building and tuning process, the environment plays a hand, for better or for worse. All traits, from biological traits like hair color and height to complex psychological traits like intelligence, are caused by complex interactions of genes and the environment.

The overemphasis on molecular biology and genetic research has created the impression that it is the wave of the future, the answer to our medical and even our social illnesses. But the methodology has its limits and it offers no reason to believe that safer or more economical ways of dealing with disease will emerge in many areas. Some believe that the most fruitful research should be on diseases whose emergence and course cannot be significantly modified by personal habits or the environment. ${ }^{231}$ Disorders such as Type 1 diabetes and Alzheimer's Disease appear to be induced by genetic mechanisms that cannot not be voluntarily or environmentally modified. Yet Type 2 diabetes can be avoided by exercise and weight loss, alcohol consumption can be reduced by higher taxes and better oversight of sales, and nicotine addiction can be modified by smoking bans, social pressure, and taxes. Environmental approaches are not as sexy as gene-based, high-tech methods, but they do work.

Furthermore, the evidence proffered by genetic studies also offers reasons for caution. ${ }^{232}$ Studies associating genes with specific diseases are typically

230. Subimal Datta, Avoidance Task Training Potentiates Phasic Pontine-Wave Density in the Rat: A Mechanism for Sleep-Dependent Plasticity, 20 J. NeUROSCI. 8607, 8607-13 (2000).

231. Kathleen R. Merikangas \& Neil Risch, Genomic Priorities and Public Health, 302 SCIENCE 599 (2003).

232. See Thomas A. Trikalinos et al., Establishment of Genetic Associations for Complex Diseases is Independent of Early Study Findings, 12 EUR. J. HuM. GENETICS 762, 768 (2004) (“[E]vidence collection and comprehensive synthesis may be useful in probing genetic associations of complex diseases, but cautious interpretation is probably always warranted."). 
wrong. ${ }^{233}$ A 1992 study found, for example, that people with two copies of a dopamine D3 receptor have a risk for schizophrenia roughly two to four times higher than others. ${ }^{234}$ But a flood of follow-up studies found no statistically significant link between the genes and the risk. ${ }^{235}$ Two recent studies noted that when a finding is first published linking a given gene with a complex disease, the likelihood that other studies will confirm the finding is roughly only one in three. ${ }^{236}$ Another recent report suggested the first publication identifying a connection between genes and illness is usually spurious; if it is true, the association is exaggerated. ${ }^{237}$

\section{Brave New Mind}

Neo-Darwinian hardliners, scholars who share the uncompromising belief in the irrelevance of the conscious mind and the illusory nature of free will, argue that human nature, including the intellect itself, is fixed in genetic concrete. ${ }^{238}$ According to these hardliners, we do not just have emotions, we have them for specific reasons; we do not just see, we parse the world in a particular fashion; we have built-in cognitive tools such as "cheater detectors," which recognize people who do not give a good return on investment. Under the hardliner view, these are all hard-wired capacities-complex and completely unconscious and automatic. ${ }^{239}$

Merlin Donald argues that, on the contrary, the capacity for consciousness is our distinguishing trait, a trait that defines human nature. The emergence of languages, symbols, many social institutions, and religions has all been driven by a felt need to extend the reach of human consciousness. The conscious mind assembles memories and skills, supervising the processes that make culture pos-

233. Jack Lucentini, Gene Association Studies Typically Wrong: Reproducible Gene-Disease Associates Are Few and Far Between, 18 THE SCIENTIST 20, 20 (2004).

234. M. A. Crocq et al., Association Between Schizophrenia and Homozygosity at the Dopamine D3 Receptor Gene, 29 J. MED. GENETICS 858, 859 (1992).

235. Erik G. Jonsson et al., Meta-analysis of the Dopamine D3 Receptor Gene (DRD3) Ser9Gly Variant and Schizophrenia, 14 PSYCHIATRIC GENETICS 9, 9-11 (2004).

236. Kirk E. Lohmuller et al., Meta-analysis of Genetic Association Studies Supports a Contribution of Common Variants to Susceptibility to Common Disease, 33 NATURE GENETICS 177, 177 (2003); John P. A. Ioannidis et al., Replication Validity of Genetic Association Studies, 29 NATURE GENETICs 306, 306-08 (2001).

237. See Lucentini, supra note 233 , at 20 (discussing the poor reproducibility of studies linking genes to diseases and disease).

238. See DonAlD, supra note 210, at 1-4 (referring to authors Daniel Dennett, Richard Dawkins, and Steven Pinker as "neo-Darwinian Hardliners"). Donald coined the term "Brave New Mind" to describe the implications of a number of recent books on the nature of consciousness. See id. at 1. See also DANIEl C. DENNETT, DARWIN's DANGEROUS IDEA: EVOlUtion AND THE MEANINGS OF LiFE (1995); Dawkins, supra note 207; Steven Pinker, The Blank Slate: The Modern Denial of HUMAN NATURE (2002).

239. See DonALD, supra note 210, at 2 ("According to ... [the hardliners'] scheme of things, all that prating religious nonsense about moral self-discipline, denying the flesh, turning the other check, gaining control over one's base desires, not coveting thy neighbor's wife, and so on is bound to fail because it contradicts our biology."). 
sible. Our capacity for consciousness is what makes us human and provides the biological basis for the generation of culture, including symbolic thought and language. ${ }^{240}$ Donald argues further that while many brains collectively and over time generated our culture, culture in turn is shaping our brains. ${ }^{241}$ "The nature and range of human conscious experience are no longer a biological given." ${ }^{242}$ Rather, human conscious experience depends on "a somewhat unpredictable interaction of brain and culture, whereby the processes of mind can be endlessly rewritten and rearranged by cultural forces." ${ }^{243}$

\section{$\mathrm{V}$ \\ CONCLUSION}

Despite an ocean of literature explaining the flaws of expert behavioral predictions, legislatures continue to attempt to include future dangerousness predictors in statutes. ${ }^{244}$ Courts, long aware that these predictions are tenuous at best, ignore their gatekeeping duties and admit future dangerousness predictions into evidence. Experts, whose training and professional literature excoriate such testimony, continue to make future dangerousness predictions. Although the eugenics experiment in social control has been long discredited, a skeptic might be forgiven for observing that it too was characterized by a flagrant disregard for the standards and methods of science, though many of its most prominent advocates, like those experts testifying to future dangerousness, were nominally scientists.

The development of a rational set of laws requires that they be founded on sound evidence. Implementation of laws through judicial decisions similarly requires sound evidence. The intellectual culture of today is one in which science, instead of literature or philosophy, takes center stage in the debate over human nature and the nature of the universe. ${ }^{245}$ But this does not mean that scientists are always right, that they have a lock on the truth. Nor does it make them immune from scientific critique. "The danger to society is not merely that it should believe wrong things, though that is great enough; but that it should become credulous, and lose the habit of testing things and inquiring into them; for then it must sink back into savagery." ${ }^{246}$

240. Id. at 8,11 .

241. Id. at 11 .

242. Id. at 321 .

243. Id. at 321-22 ("The human conscious process is a specialized adaptation for navigating the turbulent waters of culture as well as the primary channel through which cultural influence can be transmitted back to us.").

244. See, e.g., supra text accompanying notes 36-37, 39-41.

245. The face-off between these two cultures has been supplanted by a "third culture." John Brockman was convincing in showing that it is scientists, not literary intellectuals, who have the most to say on the important questions facing mankind. JOHN BROCKMAN, THE THIRD CULTURE 17 (1995).

246. Timothy J. Madigan, Introduction to W. K. ClifFord, THE ETHICS OF BELIEF AND OTHER ESSAYS 76 (1999). 
There is no such thing as absolute truth, philosopher Karl Popper has proposed; what science provides is a better and better approximation of the truth. ${ }^{247}$ Popper advised that we not attempt to prove our theories correct, but attempt to prove them wrong, because only by passing repeated tests and being constantly refined in the process, may our theories approach truth. ${ }^{248}$ Few scientists treat their pet theories so disdainfully. Nonetheless, Popper's philosophy formed the foundation for the Daubert decision, requiring judges to examine the validity of scientific testimony before admitting it in evidence. ${ }^{249}$

Legislatures and judges are under enormous public pressure to solve the problem of violent (and sexually violent) crime. Admitting the dubious testimony of experts willing to testify that an individual poses a future danger to society is an easy, but disingenuous, answer. Unfortunately, another easy answer to the problem of crime control-finding a genetic basis for executing or locking up a violent individual and throwing away the key-is similarly unsupported by evidence. Genetic determinism is simply unfounded when it comes to complex behavior. Rather, to reduce the level of violence in our society and help prevent those who committed acts of violence from repeating them, we need to develop more constructive methods of expression: $:^{250}$ whether one justifies the enforcement of social norms through a utilitarian calculus or by retributive principles, or by some hybrid combination of the two, science ought to inform the social, political, and legal debates about what violence is preventable and about what controls are likely to be effective.

Law's moral authority is based on the accuracy of its assumptions and predictions. Admitting scientifically baseless expert testimony on future dangerousness into evidence is not only cynical, it undermines law's moral authority. The very least we can do in a system that aspires to do justice is to be sure the scientific testimony admitted in our courts has been tested, scrutinized, and properly limited. If what we seek is justice, and if justice depends on the willingness to seek the truth, the current charade undermines the rule of law. A far better solution is to require that experts testifying about human behavior acknowledge the complexity of the environmental (nurture) and biological (na-

247. KARL R. PopPer, ReAlism AND the Aim of SCIENCE 25 (W.W. Bartley, III ed., 1983).

248. Id.

249. Erica Beecher-Monas \& Edgar Garcia-Rill, The Law and the Brain: Judging Scientific Evidence of Intent, 1 J. APP. PRAC. \& PROCESS 243, 247 (1999).

250. As Owen Jones noted, "law is a lever for moving human behavior." Owen D. Jones, Law and Biology: Toward an Integrated Model of Human Behavior, 8 J. CONTEMP. LEGAL ISSUES 167, 167 (1997). We ought to be fairly sure we are moving it in the right direction. There is a great need for research into early childhood intervention and for methods that are effective in rehabilitating offenders, methods that will certainly need to be individually tailored depending on the individual's major negative environmental influences. Such methods will certainly be criticized as expensive and timeconsuming, which they will be. The cost of treatment and intensive supervision in the community is estimated at about $\$ 5,000-15,000$ per individual per year; the cost of incarceration is significantly higher, $\$ 22,000$ per year, excluding treatment costs. See MYTHS AND FACTS ABOUT SEX OFFENDERS, supra note 192. What we are doing now is expensive in money and human capital too. The question then becomes, how long are we willing to stand current conditions? 
ture) interactions, and ultimately recognize that human beings can and do change their behavior. 